\title{
Signal transduction in mammalian oocytes during fertilization
}

\author{
Zoltan Machaty ${ }^{1}$
}

Received: 4 May 2015 / Accepted: 28 August 2015 /Published online: 9 October 2015

(C) The Author(s) 2015. This article is published with open access at Springerlink.com

\begin{abstract}
Mammalian embryo development begins when the fertilizing sperm triggers a series of elevations in the oocyte's intracellular free $\mathrm{Ca}^{2+}$ concentration. The elevations are the result of repeated release and re-uptake of $\mathrm{Ca}^{2+}$ stored in the smooth endoplasmic reticulum. $\mathrm{Ca}^{2+}$ release is primarily mediated by the phosphoinositide signaling system of the oocyte. The system is stimulated when the sperm causes the hydrolysis of phosphatidylinositol 4,5-bisphosphate $\left(\mathrm{PIP}_{2}\right)$ into inositol 1,4,5-trisphosphate $\left(\mathrm{IP}_{3}\right)$ and diacylglycerol $(\mathrm{DAG}) ; \mathrm{IP}_{3}$ then binds its receptor on the surface of the endoplasmic reticulum that induces $\mathrm{Ca}^{2+}$ release. The manner in which the sperm generates $\mathrm{IP}_{3}$, the $\mathrm{Ca}^{2+}$ mobilizing second messenger, has been the subject of extensive research for a long time. The sperm factor hypothesis has eventually gained general acceptance, according to which it is a molecule from the sperm that diffuses into the ooplasm and stimulates the phosphoinositide cascade. Much evidence now indicates that the sperm-derived factor is phospholipase C-zeta (PLC $\zeta$ ) that cleaves $\mathrm{PIP}_{2}$ and generates $\mathrm{IP}_{3}$, eventually leading to oocyte activation. A recent addition to the candidate sperm factor list is the postacrosomal sheath WW domain-binding protein (PAWP), whose role at fertilization is currently under debate. $\mathrm{Ca}^{2+}$ influx across the plasma membrane is also important as, in the absence of extracellular $\mathrm{Ca}^{2+}$, the oscillations run down prematurely. In pig oocytes, the influx that sustains the oscillations seems to be regulated by the filling status of the stores, whereas in the mouse other mechanisms might be involved.
\end{abstract}

Zoltan Machaty

zmachaty@purdue.edu

1 Department of Animal Sciences, Purdue University, 915 W. State Street, West Lafayette, IN 47907, USA
This work summarizes the current understanding of $\mathrm{Ca}^{2+}$ signaling in mammalian oocytes.

Keywords Oocyte $\cdot$ Signal transduction $\cdot$ Fertilization . Sperm $\cdot$ Embryo

\section{Introduction}

Prior to fertilization, mammalian oocytes are arrested at the metaphase stage of the second meiotic cell division. The meiotic block is characteristic of the entire animal kingdom and, although it may happen at various stages of the cell cycle, its role is to prevent entry into the embryonic cell cycles without the sperm (Dupré et al. 2011). The ovulated oocyte is a highly differentiated cell that, without fertilization, would die within 24-48 h. The fertilizing sperm, however, provides a stimulus that alleviates the meiotic arrest and activates the oocyte's developmental program. During activation, the content of cortical granules is released into the perivitelline space. This triggers changes in the oocyte's extracellular matrix, the zona pellucida, to prevent penetration by additional spermatozoa (Jaffe and Gould 1985). The activity of cell cycle regulatory proteins that maintain the arrest, such as cyclin-dependent kinase $1(\mathrm{Cdk} 1$; a component of the M-phase Promoting Factor) and Mitogen-Activated Protein Kinase (MAPK; part of the Cytostatic Factor) decreases, while that of others, such as the Anaphase Promoting Complex (APC) increases (Whitaker 1996; Nixon et al. 2002). As a result, the cell cycle resumes, meiosis is completed and after formation of the male and female pronuclei, the activated oocyte (now a 1-cell embryo) enters the first mitotic division. Activation is a remarkable process. It allows a differentiated cell to become totipotent and give rise to all the different cell types of a new organism. The transition is triggered by a highly intricate signal 
transduction mechanism that the sperm stimulates following sperm-oocyte fusion. This review describes the signaling pathway and discusses how it operates in mammalian oocytes to mediate the formation of an embryo, the founder of a new generation.

\section{The rise of calcium}

It was Jacques Loeb who first suggested that oocyte activation involves changes in the concentration of ions in the ooplasm (Loeb 1899). His idea was based on the observation that sea urchin eggs started to develop parthenogenetically in the absence of sperm, simply by being bathed in seawater containing increased levels of ions. At a time when embryo development was explained with "vital forces", not everybody was impressed; The New York Times referred to him simply as "a man of lively imagination". The notion, however, was so fascinating that even Mark Twain wrote an essay about it titled "Dr. Loeb's Incredible Discovery". The calcium ion $\left(\mathrm{Ca}^{2+}\right)$ was singled out by Lewis Victor Heilbrunn. Although the importance of $\mathrm{Ca}^{2+}$ in the contraction of skeletal muscle was demonstrated earlier (Ringer 1883), it was Heilbrunn who discovered that $\mathrm{Ca}^{2+}$ was the trigger not only for oocyte activation but also a great number of additional biological processes including ciliary movement, neurotransmitter release, increase or decrease in cell respiration and cell aging (Heilbrunn 1937). Considered by many in his time as a 'calcium maniac' (Shreeve 1983), Heilbrunn proposed that the breakdown of the nuclear membrane in the oocyte of the ragworm Nereis following fertilization or parthenogenetic activation was due to the release of $\mathrm{Ca}^{2+}$ inside the cell (Heilbrunn and Wilbur 1937). The increase in the free $\mathrm{Ca}^{2+}$ concentration during fertilization was quantitated in the eggs of another marine invertebrate, the sea urchin Arbacia punctulata (Mazia 1937). It was then demonstrated that treating sea urchin eggs with a $\mathrm{Ca}^{2+}$ ionophore that induced the release of $\mathrm{Ca}^{2+}$ from the intracellular stores caused parthenogenetic activation (Steinhardt and Epel 1974). The role of $\mathrm{Ca}^{2+}$ as the trigger of oocyte activation was proved when in medaka oocytes fertilization was shown accompanied by an elevation in the intracellular free $\mathrm{Ca}^{2+}$ concentration (Ridgway et al. 1977) and inhibition of this increase in sea urchin eggs blocked changes associated with activation (Zucker and Steinhardt 1978; Whitaker and Steinhardt 1982). Since these early studies, it has been firmly established that in virtually all animals it is $\mathrm{Ca}^{2+}$ that induces activation of the dormant oocyte. In most species, the sperm triggers a single elevation in the oocyte's intracellular free $\mathrm{Ca}^{2+}$ concentration. The increase generally originates at the site of sperm entry and travels across the oocyte as a propagating $\mathrm{Ca}^{2+}$ wave (Gilkey et al. 1978). However, in mammals and some other species, including nemertean worms, ascidians, some annelids and arthropods, a series of low-frequency $\mathrm{Ca}^{2+}$ oscillations take place in the ooplasm at fertilization (Stricker 1999; Kashir et al. 2013a). In these cases, the first sperm-induced $\mathrm{Ca}^{2+}$ transient also arises near the site of sperm attachment and propagates as a wave across the entire oocyte. The initiation site of subsequent waves may undergo a shift: in mouse oocytes, it translocates from the point of sperm entry to the vegetal cortex (Deguchi et al. 2000).

Oscillatory $\mathrm{Ca}^{2+}$ signals have physiological advantages over static $\mathrm{Ca}^{2+}$ increases and they affect subsequent development. The repetitive behavior provides a means to deliver prolonged $\mathrm{Ca}^{2+}$ signals to targets without the deleterious effects of sustained $\mathrm{Ca}^{2+}$ elevations. The amplitude, frequency and duration of the sperm-induced $\mathrm{Ca}^{2+}$ signals encode crucial information and have a profound effect on peri-implantation development in addition to effects on the immediate events of oocyte activation (Ozil and Huneau 2001). Although a single increase in the intracellular free $\mathrm{Ca}^{2+}$ concentration can promote parthenogenetic development, freshly ovulated oocytes showed limited cell cycle progression and mRNA recruitment following activation with a single $\mathrm{Ca}^{2+}$ stimulus and only after aging could a single $\mathrm{Ca}^{2+}$ rise stimulate these critical events (Jones 1998; Ozil et al. 2005). By manipulating the number of $\mathrm{Ca}^{2+}$ transients in fertilized mouse oocytes, it was demonstrated that the first few $\mathrm{Ca}^{2+}$ transients were able to induce development to the blastocyst stage but fewer offspring were born from these embryos, indicating that the developmental competence of the blastocysts was reduced. Microarray analysis of global gene expression patterns in these embryos revealed that $\sim 20 \%$ of the genes were misregulated, particularly those involved in RNA processing, polymerase II transcription, cell cycle and cell adhesion (Ozil et al. 2006).

\section{How does the sperm trigger the $\mathrm{Ca}^{2+}$ rise?}

Once it was clarified that oocyte activation is stimulated by $\mathrm{Ca}^{2+}$, the next question that logically occurred was how the sperm triggers the $\mathrm{Ca}^{2+}$ elevation in the ooplasm? This issue, however, remained unresolved for a long time. Multiple hypotheses were proposed to explain the generation of the fertilization $\mathrm{Ca}^{2+}$ signal. The earliest model known as the " $\mathrm{Ca}^{2+}$ bomb hypothesis" postulated that the sperm introduces $\mathrm{Ca}^{2+}$ into the oocyte that sets off a wave of $\mathrm{Ca}^{2+}$-induced $\mathrm{Ca}^{2+}$ release (Fig. 1) (Jaffe 1983). However, the $\mathrm{Ca}^{2+}$ content of the sperm is not sufficient to trigger $\mathrm{Ca}^{2+}$ release and the hypothesis was subsequently modified to suggest that the sperm serves as a $\mathrm{Ca}^{2+}$ conduit, allowing $\mathrm{Ca}^{2+}$ from the extracellular medium to flow into the ooplasm (Jaffe 1991). The $\mathrm{Ca}^{2+}$ is then pumped into the endoplasmic reticulum, which results in the overloading of the stores and the release of luminal $\mathrm{Ca}^{2+}$. Even in this form, the theory did not stand the test of time. The injection of $\mathrm{Ca}^{2+}$ into the ooplasm fails to cause 
$\mathrm{Ca}{ }^{2+}$ bomb
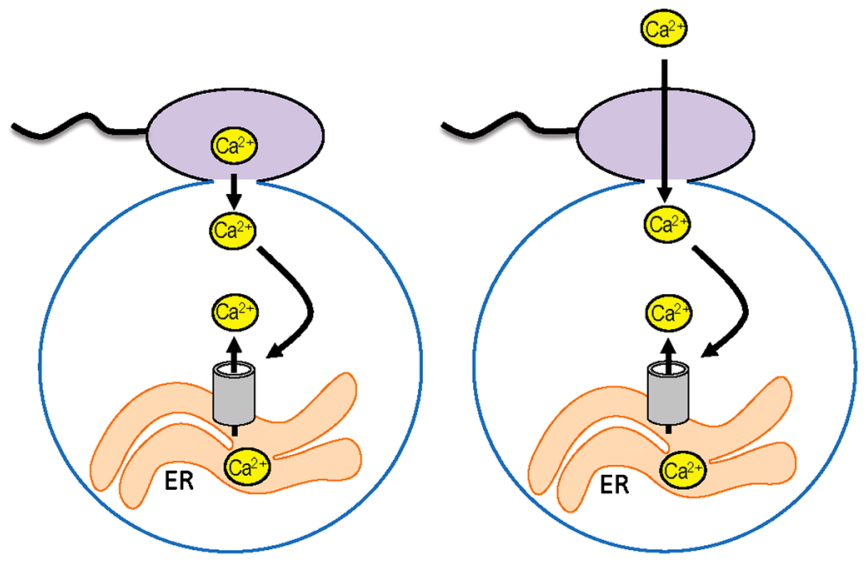

Fig. 1 Schematic illustration of various hypotheses explaining the way the fertilizing sperm induces an elevation in the intracellular free $\mathrm{Ca}^{2+}$ concentration of the oocyte. The $\mathrm{Ca}^{2+}$ bomb hypothesis proposes that the sperm delivers a bolus of $\mathrm{Ca}^{2+}$ that causes $\mathrm{Ca}^{2+}$-induced $\mathrm{Ca}^{2+}$ release in the oocyte. According to the $\mathrm{Ca}^{2+}$ conduit model, the sperm facilitates $\mathrm{Ca}^{2+}$ entry from the extracellular medium. The receptor hypothesis

further $\mathrm{Ca}^{2+}$ release in many species, or to trigger repetitive $\mathrm{Ca}^{2+}$ oscillations in mammalian oocytes (Swann and Whitaker 1986; Swann and Ozil 1994). In addition, no local elevation in the cytoplasmic $\mathrm{Ca}^{2+}$ levels has been detected near the site of sperm-oocyte fusion (Jones et al. 1998); as it turned out, a $\mathrm{Ca}^{2+}$ entry takes place after (rather than before) the first $\mathrm{Ca}^{2+}$ transient (McGuinness et al. 1996).

According to the "receptor hypothesis", the fertilizing sperm induces the $\mathrm{Ca}^{2+}$ oscillations by binding to a receptor on the surface of the oocyte plasma membrane. Just like hormone-receptor binding in somatic cells, the interaction between a sperm ligand and a receptor spanning the oolemma was proposed to activate a signaling pathway that ultimately leads to the release of $\mathrm{Ca}^{2+}$ from the endoplasmic reticulum. This hypothesis was supported by a number of observations and, for many years, it was the dominant model to explain generation of the fertilization $\mathrm{Ca}^{2+}$ signal (Jaffe 1990; Schultz and Kopf 1995). Although numerous publications suggest that oocytes contain a signaling pathway associated with cell surface receptors, there is no evidence that the sperm triggers oocyte activation via these pathways. The ligands and receptors identified so far on the surface of mammalian gametes are involved in the mediation of sperm-oocyte binding and fusion, with no role in stimulating $\mathrm{Ca}^{2+}$ release (Wassarman et al. 2005).

The "sperm factor hypothesis" proposes that oocyte activation is induced by a soluble factor in the sperm that is released into the oocyte at fertilization. In mouse, it was shown that fusion between the sperm and oocyte membranes precedes the first $\mathrm{Ca}^{2+}$ transient by 1-3 min, which is consistent with the notion that the sperm-resident factor needs time to move into the oocyte cytoplasm before it mobilizes $\mathrm{Ca}^{2+}$ from the internal stores (Lawrence et al. 1997). The finding that the

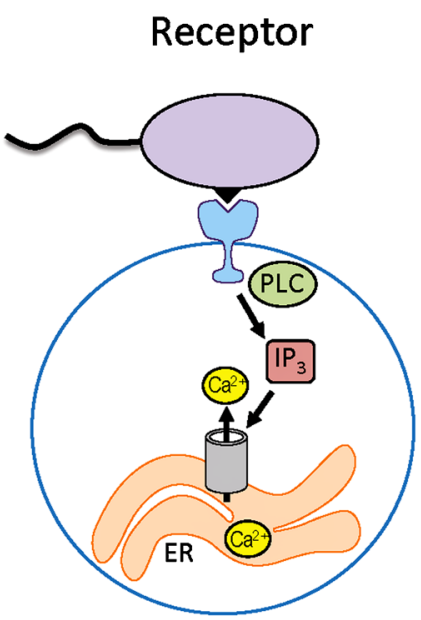

Sperm factor

suggests that $\mathrm{Ca}^{2+}$ release is induced when the sperm interacts with an oocyte receptor leading to the generation of $\mathrm{IP}_{3}$, the $\mathrm{Ca}^{2+}$ releasing second messenger. Finally, the sperm factor hypothesis claims that a factor from the sperm diffuses into the ooplasm and causes the production of $\mathrm{IP}_{3}$ to mobilize $\mathrm{Ca}^{2+}$

injection of a crude extract isolated from the head of mammalian sperm is able to induce repetitive $\mathrm{Ca}^{2+}$ oscillations in mammalian oocytes also supports this hypothesis (Swann 1990; Wu et al. 1997; Machaty et al. 2000). It was also reported that sperm extracts from fish, frogs and chickens caused oscillations in mouse oocytes (Dong et al. 2000; Coward et al. 2003). In addition, oocytes can be activated by intracytoplasmic sperm injection, where membrane interaction between the sperm and oocyte is bypassed during the injection process. This also argues in favor of the proposal that it is a factor in the sperm head that initiates the $\mathrm{Ca}^{2+}$ changes at fertilization.

\section{The signaling pathway}

The fertilizing sperm can generate the initial $\mathrm{Ca}^{2+}$ transient even in the absence of extracellular $\mathrm{Ca}^{2+}$; this led to the realization that the origin of $\mathrm{Ca}^{2+}$ that activates the oocyte is intracellular (Gilkey et al. 1978). In many cells, the intracellular stores reside in the smooth endoplasmic reticulum. $\mathrm{Ca}^{2+}$ is loaded into the lumen of the stores by sarcoplasmic/ endoplasmic reticulum $\mathrm{Ca}^{2+}$ ATPases (SERCA pumps) and stored while attached to $\mathrm{Ca}^{2+}$-binding proteins (Berridge 2002). During signaling, the stored $\mathrm{Ca}^{2+}$ is released into the cytosol through $\mathrm{Ca}^{2+}$ release channels. Two types of channels, which also function as receptors for their respective $\mathrm{Ca}^{2+}$ mobilizing ligands, are available for $\mathrm{Ca}^{2+}$ release. The inositol 1 , 4,5-trisphosphate $\left(\mathrm{IP}_{3}\right)$ receptor is a protein complex of four subunits that surround the channel pore (Mikoshiba 1993). Each subunit can bind one $\mathrm{IP}_{3}$ molecule and binding leads to the release of $\mathrm{Ca}^{2+}$ from the store. The sensitivity of the $\mathrm{IP}_{3}$ receptor to $\mathrm{IP}_{3}$ is biphasic: it is the greatest in the 
physiological range between 0.5 and $1 \mu \mathrm{M}$ (Hajnóczky and Thomas 1994). The receptor is also gated by $\mathrm{Ca}^{2+}$. Its cytoplasmic region has at least one binding site for $\mathrm{Ca}^{2+}$ (Mignery and Südhof 1990) and experimental data indicate that the receptor shows biphasic sensitivity to cytoplasmic $\mathrm{Ca}^{2+}$. Thus, regulation of the receptor is complex: it is opened by $\mathrm{IP}_{3}$ but is also desensitized by it, while low and high $\mathrm{Ca}^{2+}$ concentrations make it relatively insensitive to otherwise activating $\mathrm{IP}_{3}$ levels. The other type of $\mathrm{Ca}^{2+}$ release channels/receptors is the ryanodine receptor. It is also a homotetramer of four subunits and its opening is controlled by cyclic adenosine diphosphate ribose (cADPR), by $\mathrm{Ca}^{2+}$ itself and in skeletal muscle by electromechanical coupling to the dihydropiridine receptor located in the plasma membrane (Coronado et al. 1994).

In mammalian oocytes, the generation of the fertilization $\mathrm{Ca}^{2+}$ transients is mediated by the phosphoinositide signaling system. Such a system produces a signal when $\mathrm{IP}_{3}$ binds its receptor, leading to the opening of the channel and the release of $\mathrm{Ca}^{2+}$ into the cytosol. $\mathrm{IP}_{3}$ is produced when phospholipase C (PLC), a cytoplasmic enzyme, cleaves phosphatidylinositol 4,5-bisphosphate $\left(\mathrm{PIP}_{2}\right)$, a phosphoinositide, into $\mathrm{IP}_{3}$ and diacylglycerol (DAG) (Miyazaki et al. 1993). Currently, there are 13 known mammalian phosphoinositide-specific PLC isozymes; their classification is based on structure and regulation. They include 4 types of PLC $\beta$ (PLCbeta), 2 types of PLC $\gamma$ (PLCgamma), 3 types of PLC $\delta$ (PLCdelta), PLCE

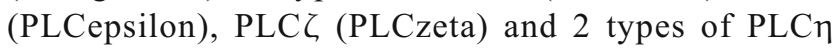
(PLCeta) (Bunney and Katan 2011). All isozymes exhibit characteristic $\mathrm{X}$ and $\mathrm{Y}$ catalytic domains that together form the active site responsible for cleaving $\mathrm{PIP}_{2}$. They also contain various combinations of regulatory domains that target the enzymes to their respective activators or substrates; these include pleckstrin homology (PH) domains, Src homology 2 (SH2) domains and constant or conserved region 2 (C2) domains. The mechanism of activation varies depending on the specific combination of regulatory domains present in each PLC isozyme. PH domains bind phosphoinositides such as $\mathrm{PIP}_{2}$ and $\mathrm{PIP}_{3}$ and thus they typically serve to target PLC to the plasma membrane where most phosphoinositides are located. In addition, they can also mediate interaction with heterotrimeric G proteins (Camps et al. 1992). SH2 domains interact with receptor tyrosine kinases and also with nonreceptor tyrosine kinases such as Src (Weiss 1993). Finally, $\mathrm{C} 2$ domains bind $\mathrm{Ca}^{2+}$ and bestow phospholipid-binding properties to the enzyme.

Several lines of evidence indicate the involvement of the phosphoinositide signaling cascade during fertilization. Biochemical analyses in sea urchin and frogs have shown an increased turnover of polyphosphoinositides and an elevation in $\mathrm{IP}_{3}$ levels after gamete interaction (Turner et al. 1984; Snow et al. 1996). In addition, a monoclonal antibody against the $\mathrm{IP}_{3}$ receptor inhibits the sperm-induced $\mathrm{Ca}^{2+}$ transients (Miyazaki et al. 1992), while sustained microinjection of $\mathrm{IP}_{3}$, or adenophostin (an $\mathrm{IP}_{3}$ analogue) can also trigger $\mathrm{Ca}^{2+}$ oscillations in mammalian oocytes (Swann 1994; Jones and Nixon 2000). Further evidence also shows that the PLC inhibitor U73122 blocks activation in the sea urchin and mouse (Dupont et al. 1996; Lee et al. 1998). Finally, in mouse and bovine oocytes, there is a significant down-regulation of the $\mathrm{IP}_{3}$ receptors, i.e., their number decreases markedly at the time of fertilization (Brind et al. 2000; Jellerette et al. 2000). Normally, this occurs only after a substantial rise in the $\mathrm{IP}_{3}$ concentration, implying that at fertilization the sperm stimulates an increase in $\mathrm{IP}_{3}$ levels in the oocyte cytoplasm. Initial investigations were focused on oocyte-resident PLCs and the presence of PLC $\beta, P L C \gamma$ and PLC $\delta$ was demonstrated in the female gamete. PLC $\beta$ isoforms are generally coupled to membrane receptors via a $G$ protein, whereas $\gamma$ isoforms are directly linked to receptor tyrosine kinases. Microinjection of a nonhydrolyzable analog of GTP that stimulates G proteins $(\mathrm{GTP} \gamma \mathrm{S})$ caused activation in sea urchin eggs (Turner et al. 1986) and induced regenerative $\mathrm{Ca}^{2+}$ rises in some mammalian oocytes (Miyazaki 1988; Swann 1992; Fissore et al. 1995). Also, overexpression of the G protein-coupled muscarinic receptor in frog, mouse and pig oocytes led to activation after exposure of the oocytes to acetylcholine, the receptor's ligand (Kline et al. 1988; Williams et al. 1992; Machaty et al. 1997). These findings suggested that the pathway that mediated $\mathrm{Ca}^{2+}$ release might include a PLC $\beta$ connected to a $\mathrm{G}$ protein-coupled receptor.

An alternative signaling mechanism that was implicated by experimental data involved PLC $\gamma$ and an associated receptor tyrosine kinase. Overexpression and subsequent stimulation of such receptors in frog and mouse oocytes leads to activation (Yim et al. 1994; Mehlmann et al. 1998), which seems to support the theory. However, recombinant SH2 domains of PLC $\gamma$ block PLC $\gamma$ activation by the receptor but they cannot inhibit $\mathrm{Ca}^{2+}$ release at fertilization (Mehlmann et al. 1998; Runft et al. 1999), which argues against the involvement of PLC $\gamma$ in the signaling process at fertilization. In addition, when the phosphoinositide signaling system is artificially activated using GTP $\gamma \mathrm{S}$, or non-hydrolyzable analogs of $\mathrm{IP}_{3}$, the $\mathrm{Ca}^{2+}$ signal that is generated is still a far cry from the low-frequency $\mathrm{Ca}^{2+}$ oscillations associated with mammalian fertilization (Miyazaki et al. 1990; Swann and Ozil 1994; Galione et al. 1994; Machaty et al. 1997). Taken together, these data indicate that the oocytes contain a phosphoinositide signaling pathway; however, the exact mechanism that mediates its activation at fertilization has not been identified by these studies.

\section{Finding PLC $\zeta$}

As described above, a number of observations supported the idea that the sperm might stimulate the phosphoinositide 
signaling pathway by introducing a soluble factor into the oocyte after fusion. This led to a quest to identify the oocyte activating factor but the efforts proved futile for a long time. The molecule was shown to be a protein since heat treatment or proteases abolished its $\mathrm{Ca}^{2+}$-inducing activity; it was also believed to have a high molecular mass and be present in cytosolic extracts (Swann 1990). Mammalian sperm extracts showed high PLC enzyme activity in biochemical assays, which suggested that the sperm factor that activates the oocyte might itself be a PLC (Rice et al. 2000). Spermatozoa of mammalian species express several PLC isoforms including PLC $\beta,-\gamma$ and $-\delta$ (Fukami 2002); however, when the recombinant forms of these proteins were injected into oocytes, they were unable to induce $\mathrm{Ca}^{2+}$ oscillations at physiological levels (Mehlmann et al. 2001). And because chromatographic fractionation of sperm extracts indicated that none of the known PLC isoforms were present in the fraction that were able to induce regenerative $\mathrm{Ca}^{2+}$ rises (Parrington et al. 2002), the idea came that the sperm factor might be a novel PLC.

The analysis of mouse expressed sequence tag (EST) databases led to the identification and eventual amplification of a new, testis-specific PLC variety, termed PLCל (Saunders et al. 2002). With its $\sim 74 \mathrm{kDa}$ molecular weight, it is the smallest known mammalian PLC. Recombinant PLC $\zeta$, or its complementary RNA (cRNA), are both able to induce regenerative $\mathrm{Ca}^{2+}$ oscillations in mouse oocytes similar to those found at fertilization (Saunders et al. 2002; Cox et al. 2002; Kouchi et al. 2004). Furthermore, when injected into human and pig oocytes, PLC $\zeta$, cRNA can stimulate embryo development to the blastocyst stage (Rogers et al. 2004; Yoneda et al. 2006). Immunodepletion with an anti-PLC $\zeta$, antibody suppressed the extracts' ability to induce $\mathrm{Ca}^{2+}$ release in mouse oocytes or sea urchin egg homogenates (Saunders et al. 2002). The presence of PLC $\zeta$, orthologues has been demonstrated in the sperm of other mammalian species, including hamster, pig, horse, monkey and human (reviewed by Nomikos et al. 2013). In mice, the protein is localized in the postacrosomal region of the perinuclear theca, a condensed layer of cytosolic proteins that covers the nucleus (Young et al. 2009); in cattle, it resides in the equatorial region of the sperm head (Yoon and Fissore 2007). This is the localization that is expected from a spermresident factor that needs to gain rapid access to the ooplasm after gamete fusion to mobilize $\mathrm{Ca}^{2+}$ (Lawrence et al. 1997). The use of tagged versions of the protein has indicated that approximately $40 \mathrm{fg} \mathrm{PLC} \zeta$, is able to trigger repetitive $\mathrm{Ca}^{2+}$ transients in mouse oocytes and this is the amount estimated to be present in a single sperm (Saunders et al. 2002). Injection of PLC $\zeta$ into mouse oocytes causes a down-regulation of $\mathrm{IP}_{3}$ receptors similar to that seen at fertilization, indicating that PLC $\zeta$ generates $\mathrm{IP}_{3}$ in the cytoplasm (Lee et al. 2010). When spermatozoa from transgenic mice showing reduced PLC $\zeta$ expression were used to fertilize oocytes, the $\mathrm{Ca}^{2+}$ oscillations generated in the ooplasm stopped prematurely
(Knott et al. 2005). Although these mice were not completely infertile, they produced markedly reduced litter sizes following mating. Sperm of human patients that failed to activate the oocyte also had deficiencies in their PLC $\zeta$ : they either showed reduced or complete absence of the enzyme, or possessed deleterious mutations within the catalytic $\mathrm{X}$ and $\mathrm{Y}$ domains (Yoon et al. 2008; Kashir et al. 2012). The analysis of sperm that is completely devoid of $\mathrm{PLC} \zeta$ would provide invaluable information regarding the role of the protein in $\mathrm{Ca}^{2+}$ signaling at fertilization. Unfortunately, although PLC $\zeta$-knockout mice have already been created, they are unable to produce sperm; the germ cells in the testes of such animals develop only up to the round spermatid stage (Ito et al. 2010). It was demonstrated some time ago (Kimura and Yanagimachi 1995) that microinjection of round mouse spermatids is unable to activate oocytes (a potential explanation to this might be that, according to one study, $\mathrm{PLC} \zeta$, expression in mice begins in elongated spermatids only [Yoneda et al. 2006]); hence, these cells cannot be used to determine the importance of $\mathrm{PLC} \zeta$, in fertilization. Nevertheless, despite the absence of this ultimate test, the data listed above strongly argue in favor of the idea that, in mammals, PLC $\zeta$ has a central role in the generation of the $\mathrm{Ca}^{2+}$ signal to activate the oocyte and stimulate embryo development.

\section{PLC $\zeta$ characteristics}

The PLC $\zeta$ orthologues identified in various mammalian species are all similar in size (Swann et al. 2006). Surprisingly, they lack the N-terminal PH domain that is present in other PLC isoforms and instead contain two pairs of $\mathrm{EF}$ hand domains, followed by the XY catalytic domain and a $\mathrm{C} 2$ domain at the $\mathrm{C}$ terminus. $\mathrm{PLC} \zeta$ is much more potent than other PLC isoforms in generating $\mathrm{Ca}^{2+}$ oscillations; its closest homologue, PLC $\delta 1$ triggers oscillations only when it is present in mouse oocytes at concentrations higher than 1 pg (Saunders et al. 2002; Nomikos et al. 2011). As in other isoforms, the XY catalytic domain is responsible for enzymatic activity; a point mutation in this domain causes a loss in the enzyme's ability to generate $\mathrm{IP}_{3}$ and induce $\mathrm{Ca}^{2+}$ oscillations (Nomikos et al. 2011). The activity is not species specific as cRNA of various mammalian or non-

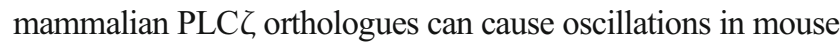
oocytes (Cox et al. 2002; Coward et al. 2005).

The EF hands possess $\mathrm{Ca}^{2+}$ binding residues and provide the enzyme with high $\mathrm{Ca}^{2+}$ sensitivity; deletion or mutation of conserved $\mathrm{Ca}^{2+}$ binding residues in this region abolish $\mathrm{Ca}^{2+}$ induced PLC activity. PLC $\zeta$ is 100 -fold more sensitive to $\mathrm{Ca}^{2+}$ than PLC $\delta$ and this is believed to be a major reason why the enzyme is highly effective in oocytes. Even at resting $\mathrm{Ca}^{2+}$ levels, $\mathrm{PLC} \zeta$ shows half maximal activity and, with rising cytosolic $\mathrm{Ca}^{2+}$ concentrations, its enzymatic activity increases markedly (Nomikos et al. 2005). Thus, following 
gamete fusion, when PLC $\zeta$ diffuses into the ooplasm, a small increase in cytosolic $\mathrm{Ca}^{2+}$ causes a significant elevation in PLC activity, leading to the generation of large amounts of extra $\mathrm{IP}_{3}$. This creates a positive feedback loop of $\mathrm{IP}_{3}$ production and $\mathrm{Ca}^{2+}$ release in fertilized oocytes, setting the stage for the regenerative $\mathrm{Ca}^{2+}$ signal.

C2 domains generally bind $\mathrm{Ca}^{2+}$ (Nalefski and Falke 1996) and $\mathrm{Ca}^{2+}$ binding to the $\mathrm{C} 2$ domain is typically crucial for enzyme activity (Zheng et al. 2000). However, the $\mathrm{C} 2$ domain of PLC $\zeta$ has no predicted $\mathrm{Ca}^{2+}$ binding site. Deletion of this domain does not alter enzyme activity of PLC $\zeta$, nevertheless it abolishes its ability to induce $\mathrm{Ca}^{2+}$ oscillations, indicating that the $\mathrm{C} 2$ domain is critical for PLC $\zeta$ function (Nomikos et al. 2005). Another segment, the XY-linker that joins together the $\mathrm{X}$ and $\mathrm{Y}$ catalytic domains, also has a major impact on PLC $\zeta$ function. As mentioned before, unlike other isoforms, PLC $\zeta$ does not have a PH domain that typically functions to bind $\mathrm{PIP}_{2}$ at the plasma membrane. It was proposed, however, that positively charged residues within this region might target the enzyme to $\mathrm{PIP}_{2}$, possibly via electrostatic interactions (Nomikos et al. 2007). A decrease in the net positive charge of the X-Y linker, or the deletion of the entire linker, caused a decline in the enzyme's ability to bind $\mathrm{PIP}_{2}$ in vitro or to induce $\mathrm{Ca}^{2+}$ oscillations after microinjection into oocytes (Nomikos et al. 2011). There are also distinct variations in the size of the $\mathrm{X}-\mathrm{Y}$ linker between species. It is the shortest in humans and the longest in the Cynomolgus monkey (Swann et al. 2006); these differences may explain the diverse potency of PLC々 orthologs to generate $\mathrm{Ca}^{2+}$ transients (Saunders et al. 2007). Finally, the $X-Y$ linker also possesses a predicted nuclear localization signal sequence that may be important in the control of PLC $\zeta$ function (Larman et al. 2004).

\section{PLC $\zeta$ localization in the sperm}

According to the sperm factor hypothesis, a compound diffuses from the sperm into the ooplasm and causes $\mathrm{Ca}^{2+}$ release from the endoplasmic reticulum. The $\mathrm{Ca}^{2+}$ oscillations begin soon after the fusion of the gametes; in the mouse, the elapsed time is approximately 1-3 min (Lawrence et al. 1997; Jones et al. 1998); in the hamster, it is shorter, about $10 \mathrm{~s}$ (Miyazaki 1991). During this time (the so-called latent period), the sperm factor is supposed to get into the ooplasm and initiate the mobilization of $\mathrm{Ca}^{2+}$. This means that the factor must reside in the sperm at a location that provides easy access to the ooplasm. It is believed that the most ideal localization for the oocyte-activating factor is the post-acrosomal region of the perinuclear theca, a condensed layer of cytosolic proteins surrounding the nucleus of the sperm (Yanagimachi 1994). Immunofluorescent analysis of mouse spermatozoa determined that PLC $\zeta$ is localized in the post-acrosomal region of the sperm head (Fujimoto et al. 2004); this region also seems to possess the ability to activate oocytes after intracytoplasmic sperm injection (Kimura et al. 1998; Perry et al. 2000). Importantly, this is the area that is exposed to the oocyte cytoplasm following fusion of the sperm's equatorial region with the oolemma. In other species, it was found in the equatorial or acrosomal region (Yoon and Fissore 2007; Kashir et al. $2013 b$ ), while in equine sperm, PLC $\zeta$ also resided in the principal piece of the tail (Bedford-Guaus et al. 2011). This latter finding was quite unexpected; however, because microinjection of the equine sperm tail caused $\mathrm{Ca}^{2+}$ oscillations into mouse oocytes (Bedford-Guaus et al. 2011), this further strengthened the idea that PLC $\zeta$ is the molecule that triggers activation.

Solubility of PLC $\zeta$ may be another aspect that influences its function as an oocyte-activating factor. Early studies in the hamster and swine determined that cytosolic extracts of the spermatozoa contained the active factor (Swann 1990); later experiments in the mouse, however, asserted that the sperm heads retained the activity after the removal of the soluble cytosolic fraction (Kimura et al. 1998; Perry et al. 2000). This seems to indicate differences among species and also variations in the solubility of PLC $\zeta$ (solubility here refers to the ability to move via diffusion in the oocyte cytosol, it does not mean that it can be extracted into an aqueous solution). In hamster, the initial $\mathrm{Ca}^{2+}$ transient begins within seconds following gamete fusion (Miyazaki 1991) and much of PLCC appears to exist in a soluble form in hamster sperm (Swann 1990) facilitating easy access to $\mathrm{PIP}_{2}$ and rapid $\mathrm{Ca}^{2+}$ mobilization in the oocyte cytoplasm. In mice, on the other hand, the $\mathrm{Ca}^{2+}$ oscillations are initiated several minutes after sperm-oocyte fusion and this relatively long latent period may be the consequence of the low solubility of mouse $\mathrm{PLC} \zeta$ that requires a longer time to move into the ooplasm from the sperm head. This idea is supported by the observation that, during isolation, the mouse sperm cytosol does not retain the oocyte-activating factor and more elaborate approaches are necessary for its extraction (Perry et al. 2000). Porcine PLC $\zeta$ has been found in both soluble and insoluble fractions (Kurokawa et al. 2005). Based on these observations, an idea has been formulated, claiming that soluble PLC $\zeta$ is located in the equatorial region of the sperm head and, due to its easy access to the ooplasm, it stimulates $\mathrm{Ca}^{2+}$ oscillations rapidly following gamete fusion. In contrast, insoluble PLC $\zeta$ localizes in the postacrosomal region and mobilizes $\mathrm{Ca}^{2+}$ in a somewhat belated manner, once incorporation of the sperm head in the oocyte cytoplasm is at a more advanced stage (Kashir et al. 2014).

\section{PLC $\zeta$ action in the oocyte}

PLC enzymes generate $\mathrm{IP}_{3}$ by cleaving the phospholipid $\mathrm{PIP}_{2}$. Because $\mathrm{PIP}_{2}$ resides solely in biological membranes, one 
would expect PLC $\zeta$ to accumulate in the plasma membrane where most of the cells' PIP $_{2}$ is located. However, fluorescently tagged mouse PLC $\zeta$ localized in the cytoplasm instead of below the oolemma (Yu et al. 2012). In addition, there is no decrease in the $\mathrm{PIP}_{2}$ concentration at the plasma membrane in mouse oocytes at fertilization (Halet et al. 2002) and the level of DAG, the other product of PIP $_{2}$ hydrolysis, does not increase at the plasma membrane during fertilization or after PLC $\zeta$ injection (Yu et al. 2008). This apparent contradiction is solved in light of the findings that $\mathrm{PIP}_{2}$ in mouse oocytes resides not only in the plasma membrane but also in the membrane of vesicles inside the oocyte cortex (Yu et al. 2012). By means of immunocytochemistry, it was determined that PLC $\zeta$ localized in the same vesicular structures and after PLC $\zeta$ injection these vesicles displayed decreased $\mathrm{PIP}_{2}$ levels. Targeting an inositol phosphate phosphatase to the plasma membrane also supported these observations. The expression of such a phosphatase in mouse oocytes reduced the amount of plasma membrane-resident $\mathrm{PIP}_{2}$ and entirely abolished the $\mathrm{Ca}^{2+}$ transients triggered by the microinjection of PLC $\delta 1$ without affecting the sperm- or PLC $\zeta$-induced $\mathrm{Ca}^{2+}$ oscillations. This also explains previous reports that extracts made of boar sperm were able to generate $\mathrm{IP}_{3}$ most effectively in the subcellular fraction of sea urchin egg homogenates that were rich in yolk vesicles (Rice et al. 2000). This suggests that $\mathrm{PLC} \zeta$ uses a unique signaling cascade to mobilize $\mathrm{Ca}^{2+}$ during fertilization when it hydrolyzes PIP $_{2}$ in intracellular membranes. The potential mechanism that PLC $\zeta$ uses to induce $\mathrm{Ca}^{2+}$ release in oocytes is shown in Fig. 2.

In mammalian oocytes, the sperm-induced $\mathrm{Ca}^{2+}$ signal oscillates for an extended period of time. In the mouse, the oscillations cease after about 3-4 h, which coincides with the formation of the male and female pronuclei. The termination of the oscillations was proposed to be due to the sequestration of $\mathrm{PLC} \zeta$ into the forming pronuclei (Marangos et al. 2003) and a number of observations support this notion. It has been shown that, if pronuclear formation is inhibited, the oscillations continue indefinitely. In addition, the oscillations are absent while the pronuclei exist but at the onset of mitosis they resume as the nuclear envelopes break down. Transferring of the male or female pronucleus from fertilized oocytes causes $\mathrm{Ca}^{2+}$ oscillations in the cytoplasm of unfertilized oocytes while pronuclei of parthenogenetically activated oocytes are unable to do so (Kono et al. 1996). Furthermore, immunocytochemical experiments indicate that recombinant mouse PLC $\zeta$ accumulates in the pronuclei upon the cessation of the oscillations (Larman et al. 2004; Yoda et al. 2004). Positively charged amino acid residues within the $\mathrm{X}-\mathrm{Y}$ linker region are probably responsible for nuclear localization as mutation of these residues to negatively charged ones results in a loss of the nuclear translocation ability and in the persistence of oscillations after pronuclear formation (Larman et al. 2004). This suggests that nuclear sequestration of $\mathrm{PLC} \zeta$ is the reason for the cessation of the oscillations and it also explains why the oscillations resume at nuclear envelope breakdown, when the first mitotic division begins. Interestingly, nuclear sequestration of PLC $\zeta$ seems to be characteristic in the mouse only, as bovine, rat and human PLC $\zeta$ do not accumulate in the pronuclei, even in mouse oocytes following ectopic expression (Ito et al. 2008). Furthermore, rat PLC $\zeta$ does not accumulate in the pronuclei of rat zygotes but mouse PLC $\zeta$ does. It has also been reported that, in bovine and rabbit zygotes, the oscillations continue beyond pronucleus formation (Fissore et al. 1992; Fissore and Robl 1993). This indicates that additional factors may also control the $\mathrm{Ca}^{2+}$ signal and currently it is unclear how the $\mathrm{Ca}^{2+}$ oscillations in species other than the mouse are terminated.

\section{Other proposed sperm factors}

A number of additional molecules have also been proposed to serve as a sperm-resident activating factor. The first candidate was "oscillin", a protein isolated by serial chromatographic purification from hamster sperm. The protein seemed to be an oscillogen, as it co-migrated with the ability of the extract to trigger $\mathrm{Ca}^{2+}$ oscillations in oocytes (Parrington et al. 1996). However, recombinant oscillin did not cause $\mathrm{Ca}^{2+}$ oscillations in oocytes, indicating that it was not the active factor in the sperm (Wolosker et al. 1998). Another candidate sperm factor was tr-kit, a truncated form of the c-kit receptor (Sette et al. 1997). In mouse oocytes, tr-kit induced parthenogenetic activation and it was suggested that it stimulated PLC $\gamma 1$ through phosphorylation by Fyn, a Src-like kinase (Sette et al. 2002). Nevertheless, although its action is inhibited by a PLC $\gamma$ SH3 construct, the same construct has no effect on sperm-induced oocyte activation (Mehlmann et al. 1998). In addition, there is no evidence to indicate that tr-kit is able to induce regenerative $\mathrm{Ca}^{2+}$ oscillations, which would be an expectation from a bona fide sperm factor.

The latest addition to the list of potential sperm factors is the postacrosomal sheath WW domain-binding protein (PAWP). WW domains are small functional modules found in many signaling and structural proteins and are known to mediate protein-protein interactions. They are named after their two signature tryptophan (W) residues that play an important role in the domains' function. Interaction between WW domain-containing proteins and their ligands is important for a great number of cellular events such as transcriptional activation, cell cycle control and ubiquitin ligation (Sudol and Hunter 2000; Macias et al. 2002). WW domains fall into two major groups (Group I and Group II) based on their ligand preferences, PAWP specifically binds to Group I WW domains (Wu et al. 2007a). PAWP expression begins during spermatid elongation in humans, rhesus monkey, mice, cows, pigs and rabbits (Wu et al. 2007a, b; Aarabi et al. 2014a) and 
Fig. 2 Hypothetical mechanism of PLC $\zeta$-induced $\mathrm{Ca}^{2+}$ release. Following gamete fusion, $\mathrm{PLC} \zeta$ diffuses into the ooplasm and hydrolyses $\mathrm{PIP}_{2}$ located in the membrane of cytoplasmic vesicles. It is possible that it binds to a yet-to-be-identified protein in the vesicular membrane (symbolized by a red rectangle). The $\mathrm{IP}_{3}$ generated as a result of the hydrolysis moves to the endoplasmic reticulum and induces the release of stored $\mathrm{Ca}^{2+}$. Elevated $\mathrm{Ca}^{2+}$ levels lead to increased $\mathrm{PLC} \zeta$ activity, which, through a positive feedback loop, stimulates further increase of $\mathrm{Ca}^{2+}$ and $\mathrm{IP}_{3}$ (from Swann and Lai 2013, with permission)

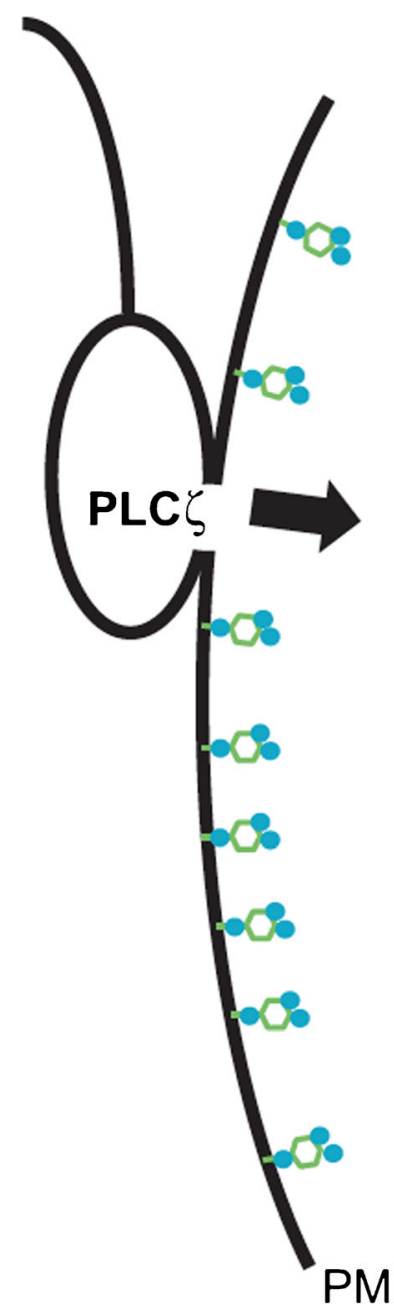

PM
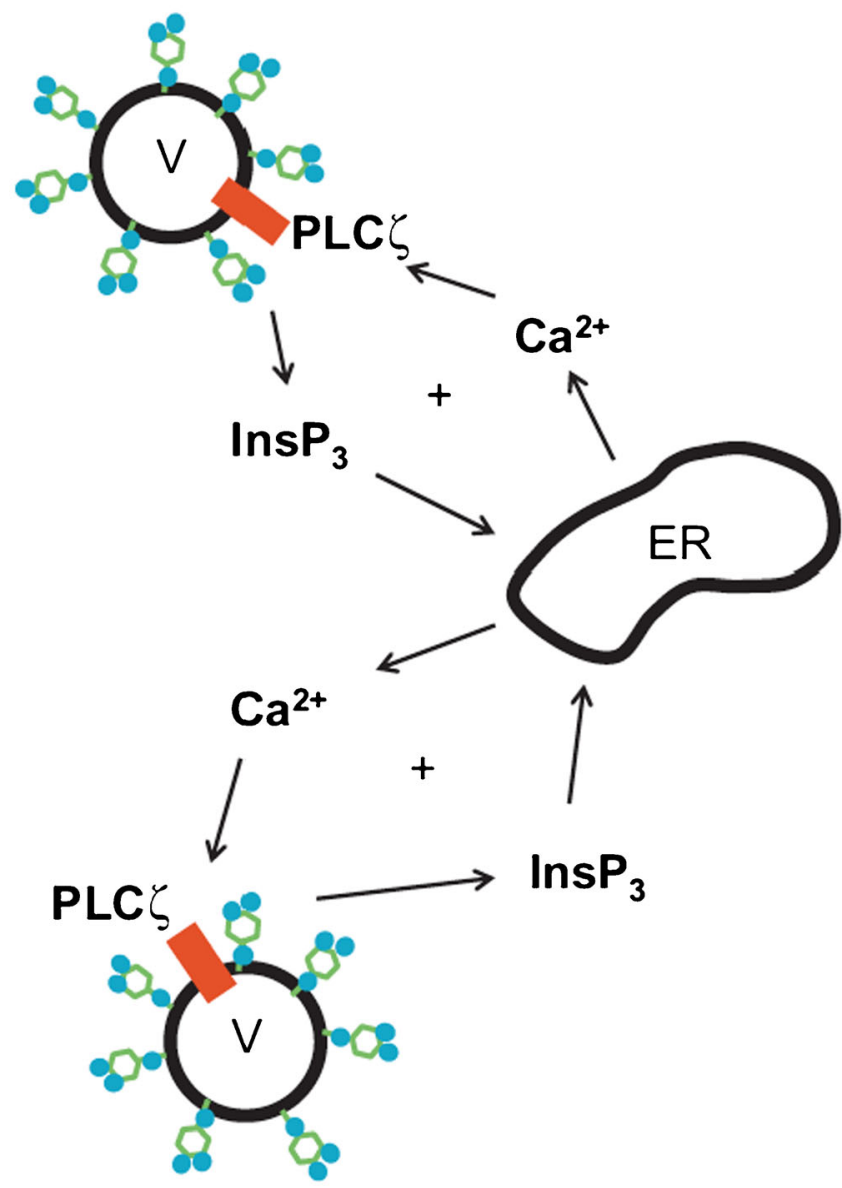

the expressed protein resides in the postacrosomal sheath of the perinuclear theca, a localization that allows rapid access to the ooplasm. It has also been demonstrated that, after spermoocyte fusion, PAWP is released into the oocyte cytoplasm (Wu et al. 2007a, b). Microinjection of recombinant PAWP into Xenopus oocytes causes $\mathrm{Ca}^{2+}$ release (Aarabi et al. 2010), while in Xenopus, porcine, bovine and macaque oocytes, it was shown to trigger cell cycle progression and pronuclear formation (Wu et al. 2007a). In addition, the recombinant protein, or its cRNA, has been shown to trigger $\mathrm{Ca}^{2+}$ oscillations in mouse and human oocytes. The oscillations are blocked by co-injection of a peptide derived from the WWI domain-binding motif of PAWP that acts as a competitive inhibitor (Aarabi et al. 2014a). This inhibitory peptide is also able to block the $\mathrm{Ca}^{2+}$ transients after intracytoplasmic sperm injection, which implies that PAWP is involved in oocyte activation at fertilization. Correlative analyses in humans and livestock species have shown that inadequate amounts of PAWP in spermatozoa are associated with low fertility, possibly because such sperm are unable to trigger oocyte activation (Aarabi et al. 2014b). It has been suggested that, once PAWP is released into the oocyte, it interacts with Group I WW domain-containing proteins, such as the yes-associated protein (YAP). These proteins are highly expressed in oocytes and possess a SH3 binding motif (Chen and Sudol 1995); they may in turn activate PLC $\gamma$ noncanonically, via its $\mathrm{SH} 3$ domain (Aarabi et al. 2014b). Such activation of PLC $\gamma$, i.e., via its SH3 instead of SH2 domain, has been observed in Xenopus oocytes and human neurons (Browaeys-Poly et al. 2007; Reynolds et al. 2008). However, since the microinjection of fusion proteins containing the SH3 domain of PLC $\gamma$ did not inhibit fertilization in mouse oocytes (Mehlmann et al. 1998), it is still not clear what signaling cascade PAWP might use to trigger $\mathrm{Ca}^{2+}$ oscillations. In addition, the ability of mouse PAWP to trigger repetitive $\mathrm{Ca}^{2+}$ transients could not be verified by others (Nomikos et al. 2014, 2015b). Furthermore, in a most recent study, human PAWP was not able to induce $\mathrm{Ca}^{2+}$ oscillations in mouse oocytes and the PAWP-derived inhibitory peptide was also unable to block sperm-induced $\mathrm{Ca}^{2+}$ oscillations (Nomikos et al. 2015a). Detailed analyses of PAWP structure and function are also missing (Kashir et al. 2015); because of these reasons, the recognition of PAWP as the sperm-derived molecule that causes oocyte activation at fertilization requires further verification. 


\section{$\mathrm{Ca}^{2+}$ influx}

Once the $\mathrm{Ca}^{2+}$ signal is initiated, in mammalian oocytes it takes the form of repetitive $\mathrm{Ca}^{2+}$ oscillations. It is not completely clear what causes the signal to oscillate; the complex regulation and basic feedback properties of the $\mathrm{IP}_{3}$ receptor are usually listed as the most likely causes (Berridge and Galione 1988). In addition, the oscillations also depend on $\mathrm{Ca}^{2+}$ influx. After each $\mathrm{Ca}^{2+}$ rise, the resting $\mathrm{Ca}^{2+}$ level is rapidly restored. SERCA pumps move $\mathrm{Ca}^{2+}$ back into the endoplasmic reticulum (Kline and Kline 1992) and $\mathrm{Ca}^{2+}$ uptake by mitochondria may also be significant (Eisen and Reynolds 1985). At the same time, plasma membrane $\mathrm{Ca}^{2+}$ ATPase (PMCA) pumps and $\mathrm{Na}^{+} / \mathrm{Ca}^{2+}$ exchangers in the plasma membrane are also available for $\mathrm{Ca}^{2+}$ removal (Carroll 2000). In fact, a substantial efflux of $\mathrm{Ca}^{2+}$ was demonstrated in sea urchin eggs, frog and mouse oocytes after $\mathrm{Ca}^{2+}$ release (Steinhardt and Epel 1974; Shapira et al. 1996; Pepperell et al. 1999) and this outward $\mathrm{Ca}^{2+}$ current might be so substantial that the entry of extracellular $\mathrm{Ca}^{2+}$ becomes necessary to compensate for the loss. The need for $\mathrm{Ca}^{2+}$ entry to sustain the oscillations was first demonstrated in hamster oocytes. In these cells, the repetitive hyperpolarizations in the membrane potential (that were caused by a $\mathrm{K}^{+}$conductance activated by the sperm-induced $\mathrm{Ca}^{2+}$ transients) were reduced in frequency and ultimately stopped upon superfusion with $\mathrm{Ca}^{2+}$-free medium (Igusa and Miyazaki 1983). In a similar manner, the train of $\mathrm{Ca}^{2+}$ spikes in fertilized mouse oocytes slows down or stops if $\mathrm{Ca}^{2+}$ is removed from the extracellular medium (Kline and Kline 1992; Shiina et al. 1993). Additional data supporting the function of a $\mathrm{Ca}^{2+}$ influx mechanism during fertilization were provided by experiments using dithiothreitol (DTT), a sulfhydryl reducing agent. In unfertilized mouse oocytes, DTT is able to stimulate the influx of divalent cations (including $\mathrm{Ca}^{2+}$ ), whereas in fertilized ones it increases the frequency of the $\mathrm{Ca}^{2+}$ oscillations (Cheek et al. 1993). This also implies that $\mathrm{Ca}^{2+}$ entry has an important role in signaling at fertilization. The link between the $\mathrm{Ca}^{2+}$ influx and the $\mathrm{Ca}^{2+}$ transients has been analyzed in fertilized mouse oocytes. According to the study, the rising phase of each transient is followed by an increase in $\mathrm{Ca}^{2+}$ entry, while the influx weakens (but still persists) between the transients (McGuinness et al. 1996). Results from another report also indicated that, during the initial $\mathrm{Ca}^{2+}$ release in sperm extract-injected mouse oocytes, a $\mathrm{Ca}^{2+}$ influx is generated and persists throughout the oscillations (Mohri et al. 2001). These observations all support the concept that the sperminduced $\mathrm{Ca}^{2+}$ oscillations are associated with a $\mathrm{Ca}^{2+}$ influx across the plasma membrane and that the extracellular $\mathrm{Ca}^{2+}$ is essential for the refilling of the $\mathrm{Ca}^{2+}$ stores (Miyazaki 1991). They also seem to suggest that the filling status of the stores controls the influx: the release of $\mathrm{Ca}^{2+}$ from the endoplasmic reticulum apparently triggers the $\mathrm{Ca}^{2+}$ entry mechanism.
Other potential mechanisms to mediate the $\mathrm{Ca}^{2+}$ influx initially included voltage-operated channels but they were quickly ruled out. Hamster oocytes contain voltage-gated $\mathrm{Ca}^{2+}$ channels (Miyazaki and Igusa 1981); however, as sustained hyperpolarization of the oolemma increases the frequency of the sperm-induced hyperpolarization responses, their involvement is highly questionable (Miyazaki 1991). Voltage-gated $\mathrm{Ca}^{2+}$ channels have also been demonstrated in mouse oocytes (Murnane and De Felice 1993; Day et al. 1995) but because mouse oocytes show only negligible hyperpolarizations during fertilization (Igusa et al. 1983), it is unlikely that such channels mediate the $\mathrm{Ca}^{2+}$ influx.

In many cell types, the $\mathrm{Ca}^{2+}$ signal is biphasic: the release of $\mathrm{Ca}^{2+}$ from the intracellular stores is followed by $\mathrm{Ca}^{2+}$ influx across the plasma membrane. The mechanism is known as store-operated $\mathrm{Ca}^{2+}$ entry and it is a major signaling pathway in non-excitable cells (Putney 1986). In some cases, the extracellular $\mathrm{Ca}^{2+}$ entering the cell serves to keep cytoplasmic $\mathrm{Ca}^{2+}$ levels elevated and thus has a major role in the generation of the $\mathrm{Ca}^{2+}$ signal; in other cases, it helps to maintain the repetitive signal by refilling the intracellular stores (for a review, see Putney and Tomita 2012). In oocytes, it was also found that mobilizing the stored $\mathrm{Ca}^{2+}$ generated a $\mathrm{Ca}^{2+}$ influx across the plasma membrane. In mouse oocytes, depleting the intracellular stores with thapsigargin, an inhibitor of the SERCA pumps, activated a Ca ${ }^{2+}$ influx (Kline and Kline 1992). $\mathrm{Ca}^{2+}$ is known to slowly leak out of the endoplasmic reticulum via the 'leak pathway' and, because the blocked pumps are unable to reload $\mathrm{Ca}^{2+}$, the stores become depleted. The fact that store-depletion triggers a $\mathrm{Ca}^{2+}$ influx, without the activation of the phosphoinositide cascade, indicates that store-operated $\mathrm{Ca}^{2+}$ entry is functional in oocytes and may serve to refill the endoplasmic reticulum. Incubation in the presence of thapsigargin was later found to also stimulate $\mathrm{Ca}^{2+}$ entry in pig and human oocytes (Machaty et al. 2002; Martín-Romero et al. 2008), indicating that the mechanism might have a role in $\mathrm{Ca}^{2+}$ signaling.

Previous research suggested that the $\mathrm{Ca}^{2+}$ entry triggered by the filling status of the $\mathrm{Ca}^{2+}$ store is under the regulation of protein kinase $\mathrm{C}$ (PKC). 12-O-tetradecanoyl phorbol acetate (TPA) and phorbol-12-myristate-13-acetate (PMA) are phorbol esters that can very effectively stimulate PKC. When applied to mouse oocytes, they cause low amplitude $\mathrm{Ca}^{2+}$ oscillations and a variety of oocyte activation events downstream of the $\mathrm{Ca}^{2+}$ signal (Cuthbertson and Cobbold 1985; Endo et al. 1986; Colonna et al. 1989; Ducibella et al. 1991). PKC activation also promoted $\mathrm{Ca}^{2+}$ influx and repetitive $\mathrm{Ca}^{2+}$ oscillations (Yu et al. 2008), while constitutively active $\mathrm{PKC}$ constructs triggered a persistent elevation in cytosolic $\mathrm{Ca}^{2+}$ levels after the release of $\mathrm{Ca}^{2+}$ from the internal stores (Madgwick et al. 2005). In addition, 1-oleyl-2-acetylsn-glycerol (OAG), a synthetic analogue of endogenous diacylglycerol, the physiological activator of PKC, induces activation of mouse oocytes (Colonna et al. 1989). It has also been 
demonstrated that, in fertilized mouse oocytes, fluorescently labeled PKCs translocate repeatedly to the plasma membrane and the translocations occur in synchrony with the $\mathrm{Ca}^{2+}$ transients and the periodic increases in the rate of $\mathrm{Ca}^{2+}$ influx (Halet et al. 2004). On the other hand, inhibition of PKCs with bisindolylmaleimide I (BIM) blocks thapsigargin-induced $\mathrm{Ca}^{2+}$ influx and terminates the sperm-induced $\mathrm{Ca}^{2+}$ oscillations. It is possible that the $\mathrm{Ca}^{2+}$ entry channel in the plasma membrane or some accessory proteins are phosphorylated by $\mathrm{PKC}$ that in turn results in an increase in $\mathrm{Ca}^{2+}$ entry. These data imply that PKC is involved in the regulation of cytoplasmic $\mathrm{Ca}^{2+}$ levels in the oocyte, potentially by controlling a store-operated entry mechanism.

Store-operated $\mathrm{Ca}^{2+}$ entry in somatic cells is mediated by the interaction of two proteins, the stromal-interacting molecule (STIM) and Orai proteins. STIM1 and STIM2 are transmembrane proteins that reside in the endoplasmic reticulum (Liou et al. 2005; Roos et al. 2005). With an EF hand located inside the lumen of the store, they are able to sense its $\mathrm{Ca}^{2+}$ content. Upon $\mathrm{Ca}^{2+}$ mobilization, STIM1 forms small clusters (puncta), relocates to regions close to the plasma membrane and activates the $\mathrm{Ca}^{2+}$ entry channels. The channel is formed by Orai proteins (Orai1, Orai2 and Orai3). Orai1, the most potent isoform, resides in the oolemma and, once stimulated by STIM1, it allows $\mathrm{Ca}^{2+}$ in the extracellular medium to flow into the cell (Feske et al. 2006; Vig et al. 2006; Zhang et al. 2006). Both STIM1 and Orail have been identified in pig, mouse and frog oocytes (Koh et al. 2007; Gómez-Fernández et al. 2009, 2012; Yu et al. 2009; Wang et al. 2012). In the frog, where the fertilizing sperm triggers a single $\mathrm{Ca}^{2+}$ transient to activate the oocyte, store-operated $\mathrm{Ca}^{2+}$ entry is markedly down-regulated during maturation (Yu et al. 2009). In pig oocytes, the situation seems to be different. Down-regulation of STIM1 using siRNAs leads to a complete elimination of the $\mathrm{Ca}^{2+}$ oscillations associated with fertilization (Lee et al. 2012). Similarly, Orai1 knockdown inhibits store-operated $\mathrm{Ca}^{2+}$ entry and abolishes the sperm-induced $\mathrm{Ca}^{2+}$ transients (Wang et al. 2012), while specific inhibitors of store-operated $\mathrm{Ca}^{2+}$ entry were also effective in disrupting the repetitive $\mathrm{Ca}^{2+}$ signal at fertilization (Wang et al. 2015). This indicates that the $\mathrm{Ca}^{2+}$ influx that sustains the regenerative $\mathrm{Ca}^{2+}$ signal at fertilization is operated by the filling status of the stores and is mediated by STIM1 and Orail proteins.

Interestingly, inhibition of store-operated $\mathrm{Ca}^{2+}$ entry in mouse oocytes using pharmacological agents, or by preventing STIM1-Orai1 interaction through the expression of specific protein fragments, does not prevent the sperm-induced $\mathrm{Ca}^{2+}$ oscillations (Miao et al. 2012; Takahashi et al. 2013). This implies that mouse oocytes apply a $\mathrm{Ca}^{2+}$ entry mechanism other than that controlled by the intracellular store to maintain $\mathrm{Ca}^{2+}$ oscillations at fertilization. As mentioned above, the $\mathrm{Ca}^{2+}$ influx in the mouse seems to be under the control of PKC. A candidate channel to provide $\mathrm{Ca}^{2+}$ influx at fertilization is the transient receptor potential (TRP) channel. The TRP protein serves as a $\mathrm{Ca}^{2+}$ channel in a number of cell types and is expressed in various oocytes (Petersen et al. 1995; Machaty et al. 2002). Certain TRP isoforms are known to be regulated by PKC (Hardie 2007), which would account for the stimulatory effect of PKC on the sperm-induced $\mathrm{Ca}^{2+}$ signal. However, recent research has indicated that the TRP channel is not required for normal fertilization (Carvacho et al. 2013). Stimulation of TRPV3 channels leads to $\mathrm{Ca}^{2+}$ entry and subsequent oocyte activation but oocytes collected from transgenic mice that lack TRPV3 channels are able to generate the repetitive $\mathrm{Ca}^{2+}$ spikes characteristic of normal fertilization. This shows that TRPV 3 is not essential to sustain the regenerative $\mathrm{Ca}^{2+}$ signal and thus the identity of the $\mathrm{Ca}^{2+}$ entry mechanism that operates in mouse oocytes at fertilization is still unclear.

\section{Future prospects}

We have come a long way in the understanding of oocyte activation since Jacques Loeb's "incredible discovery" and our knowledge regarding the signaling event that marks the formation of a new embryo has increased tremendously. We know that the fertilizing sperm triggers development by inducing an elevation in the oocyte's cytosolic $\mathrm{Ca}^{2+}$ concentration. The source of $\mathrm{Ca}^{2+}$ is intracellular and, in mammals, the release is mediated by the phosphoinositide signaling system of the oocyte. It is also well accepted that the sperm stimulates this signaling cascade by introducing a soluble factor into the ooplasm after gamete fusion. Several lines of evidence support the idea that this key factor is phospholipase $\mathrm{C} \zeta$, a spermspecific enzyme that, after gamete fusion, cleaves $\mathrm{PIP}_{2}$ and thus generates $\mathrm{IP}_{3}$ to mobilize stored $\mathrm{Ca}^{2+}$. PLC $\zeta$ is fairly well characterized but we do not know how it finds $\mathrm{PIP}_{2}$ that resides in cytoplasmic vesicles, why it ignores $\mathrm{PIP}_{2}$ in the plasma membrane and whether or not its effect is mediated by a specific protein in the oocyte (Swann and Lai 2013). It is also unclear if it is the only sperm-derived oocyte-activating factor or if it acts in concert with other molecules such as PAWP, the latest addition to the sperm factor candidate list. Finally, the nature of the $\mathrm{Ca}^{2+}$ influx mechanism that is responsible to sustain the lowfrequency $\mathrm{Ca}^{2+}$ oscillations also needs further clarification.

A better understanding of the signaling mechanism that operates at fertilization offers major benefits. Proper activation of the oocyte's developmental program is critical not only during fertilization under normal physiological conditions but also for the success of a number of assisted reproductive technologies. Genetically modified animals have vast potentials and one powerful technology to generate such animals is somatic cell nuclear transfer. Artificial oocyte activation is an integral part of the technology; however, our inability to properly activate the reconstructed oocyte is one of the reasons for the extreme inefficiency of nuclear transfer procedures 
(Prather 1996). Because we do not completely know the underlying mechanism that mediates $\mathrm{Ca}^{2+}$ signaling in fertilized oocytes, we are not able to artificially induce the repetitive signals. Parthenogenetic activation methods generate $\mathrm{Ca}^{2+}$ changes that do not faithfully recapitulate those occurring after fertilization and this results in poor embryo development. Increasing our knowledge of how the sperm triggers the oscillatory $\mathrm{Ca}^{2+}$ signals will enhance our ability to more precisely control the process of signaling. Also, infertility in humans is a condition affecting more than 70 million (roughly 1 in 7) couples worldwide (Ledger 2008; Ombelet et al. 2008). Although a number of assisted reproductive technologies are available to alleviate the problem, conditions such as severe male factor infertility remain a formidable challenge. Intracytoplasmic sperm injection is a procedure that delivers the sperm directly into the ooplasm and, because it is highly effective in improving fertility rates, its popularity is now on a par with in vitro fertilization (Palermo et al. 2009). However, even this powerful technique can ensure only a clinical pregnancy rate of up to $45 \%$ and the primary reason for the unsuccessful cycles is a failure in oocyte activation. Clinical data indicate that the activation deficiencies are associated with reduced levels of PLC $\zeta$ (Yoon et al. 2008; Heytens et al. 2009) or PAWP (Aarabi et al. 2014b). PLC $\zeta$ deficiency has been successfully counteracted with co-injection with mouse PLC $\zeta$ mRNA (Yoon et al. 2008), while PAWP levels are also believed to have a predictive value in sperm fertilizing ability and, if confirmed to be an oocyte-activating factor, may also have application in the treatment of infertility (Aarabi et al. 2014b). Thus, the injection of a purified, active recombinant protein into the oocyte may have high therapeutic importance. The use of such a protein will also make it possible to assess how the extracellular medium shapes $\mathrm{Ca}^{2+}$ oscillations, as media composition reportedly affects $\mathrm{Ca}^{2+}$ signaling and subsequent embryo development (Dumollard et al. 2006; Banrezes et al. 2011). Characterizing the sperm factor that initiates the $\mathrm{Ca}^{2+}$ signal, along with the entire mechanism that is set in motion by the factor, will ultimately lead to the development of methods to effectively activate oocytes when spermatozoa are unable to do so.

Open Access This article is distributed under the terms of the Creative Commons Attribution 4.0 International License (http:// creativecommons.org/licenses/by/4.0/), which permits unrestricted use, distribution and reproduction in any medium, provided you give appropriate credit to the original author(s) and the source, provide a link to the Creative Commons license and indicate if changes were made.

\section{References}

Aarabi M, Balakier H, Bashar S, Moskovtsev SI, Sutovsky P, Librach CL, Oko R (2014a) Sperm-derived WW domain-binding protein, PAWP, elicits calcium oscillations and oocyte activation in humans and mice. FASEB J 28:4434-4440

Aarabi M, Balakier H, Bashar S, Moskovtsev SI, Sutovsky P, Librach CL, Oko R (2014b) Sperm content of postacrosomal WW binding protein is related to fertilization outcomes in patients undergoing assisted reproductive technology. Fertil Steril 102:440-447

Aarabi M, Qin Z, Xu W, Mewburn J, Oko R (2010) Sperm-borne protein, PAWP, initiates zygotic development in Xenopus laevis by eliciting intracellular calcium release. Mol Reprod Dev 77:249-256

Banrezes B, Sainte-Beuve T, Canon E, Schultz RM, Cancela J, Ozil JP (2011) Adult body weight is programmed by a redox-regulated and energy-dependent process during the pronuclear stage in mouse. PLoS ONE 6, e29388

Bedford-Guaus SJ, McPartlin LA, Xie J, Westmiller SL, Buffone MG, Roberson MS (2011) Molecular cloning and characterization of phospholipase $\mathrm{C}$ zeta in equine sperm and testis reveals speciesspecific differences in expression of catalytically active protein. Biol Reprod 85:78-88

Berridge MJ (2002) The endoplasmic reticulum: a multifunctional signaling organelle. Cell Calcium 32:235-249

Berridge MJ, Galione A (1988) Cytosolic calcium oscillators. FASEB J 2: 3074-3082

Brind S, Swann K, Carroll J (2000) Inositol 1,4,5-trisphosphate receptors are downregulated in mouse oocytes in response to sperm or adenophostin A but not to increases in intracellular $\mathrm{Ca}^{2+}$ or egg activation. Dev Biol 223:251-265

Browaeys-Poly E, Broutin I, Antoine AF, Marin M, Lescuyer A, Vilain JP, Ducruix A, Cailliau K (2007) A non-canonical Grb2-PLC- $\gamma 1$ Sos cascade triggered by lipovitellin 1, an apolipoprotein B homologue. Cell Signal 19:2540-2548

Bunney TD, Katan M (2011) PLC regulation: emerging pictures for molecular mechanisms. Trends Biochem Sci 36:88-96

Camps M, Carozzi A, Schnabel P, Scheer A, Parker PJ, Gierschik P (1992) Isozyme- selective stimulation of phospholipase $\mathrm{C}-\beta 2$ by $\mathrm{G}$ protein $\beta \gamma$-subunits. Nature 360:684-686

Carroll $\mathrm{J}(2000) \mathrm{Na}^{+}-\mathrm{Ca}^{2+}$ exchange in mouse oocytes: modifications in the regulation of intracellular free $\mathrm{Ca}^{2+}$ during oocyte maturation. $\mathrm{J}$ Reprod Fertil 118:337-342

Carvacho I, Lee HC, Fissore RA (2013) Clapham DE 2013) TRPV3 channels mediate strontium- induced mouse-egg activation. Cell Rep 5:1375-1386

Cheek TR, McGuinness OM, Vincent C, Moreton RB, Berridge MJ, Johnson MH (1993) Fertilisation and thimerosal stimulate similar calcium spiking patterns in mouse oocytes but by separate mechanisms. Development 119:179-189

Chen HI, Sudol M (1995) The WW domain of Yes-associated protein binds a proline-rich ligand that differs from the consensus established for Src homology 3-binding modules. Proc Natl Acad Sci U S A 92:7819-7823

Colonna R, Tatone C, Malgaroli A, Eusebi F, Mangia F (1989) Effects of protein kinase $\mathrm{C}$ stimulation and free $\mathrm{Ca}^{2+}$ rise in mammalian egg activation. Gamete Res 24:171-183

Coronado R, Morrissette J, Sukhareva M, Vaughan DM (1994) Structure and function of ryanodine receptors. Am J Physiol 266:C1485C1504

Coward K, Campos-Mendoza A, Larman M, Hibbitt O, McAndrew B, Bromage N, Parrington J (2003) Teleost fish spermatozoa contain a cytosolic protein factor that induces calcium release in sea urchin egg homogenates and triggers calcium oscillations when injected into mouse oocytes. Biochem Biophys Res Commun 305:299304

Coward K, Ponting CP, Chang HY, Hibbitt O, Savolainen P, Jones KT, Parrington J (2005) Phospholipase C $\zeta$, the trigger of egg activation in mammals, is present in a non-mammalian species. Reproduction 130:157-163 
Cox LJ, Larman MG, Saunders CM, Hashimoto K, Swann K, Lai FA (2002) Sperm phospholipase $C \zeta$ from humans and cynomolgus monkeys triggers $\mathrm{Ca}^{2+}$ oscillations, activation and development of mouse oocytes. Reproduction 124:611-623

Cuthbertson KS, Cobbold PH (1985) Phorbol ester and sperm activate mouse oocytes by inducing sustained oscillations in cell $\mathrm{Ca}^{2+}$. Nature 316:541-542

Day M, Johnson MH, Cook D (1995) Changes in inward peak $\mathrm{Ca}^{2+}$ current during progression of the cell cycle in early embryos. Proc Physiol Soc 1995:74

Deguchi R, Shirakawa H, Oda S, Mohri T, Miyazaki S (2000) Spatiotemporal analysis of $\mathrm{Ca}^{2+}$ waves in relation to the sperm entry site and animal-vegetal axis during $\mathrm{Ca}^{2+}$ oscillations in fertilized mouse eggs. Dev Biol 218:299-313

Dong JB, Tang TS, Sun FZ (2000) Xenopus and chicken sperm contain a cytosolic soluble protein factor which can trigger calcium oscillations in mouse eggs. Biochem Biophys Res Commun 268:947-951

Ducibella T, Duffy P, Kurasawa S, Kopf GS, Schultz RM (1991) The cortical reaction and modifications of the zona pellucida are stimulated by protein kinase $\mathrm{C}$ agonists in the mouse egg. J Cell Biol 115: $461 \mathrm{a}$

Dumollard R, Duchen M, Sardet C (2006) Calcium signals and mitochondria at fertilisation. Semin Cell Dev Biol 17:314-323

Dupont G, McGuinness OM, Johnson MH, Berridge MJ, Borgese F (1996) Phospholipase $\mathrm{C}$ in mouse oocytes: characterization of $\beta$ and $\gamma$ isoforms and their possible involvement in sperm-induced $\mathrm{Ca}^{2+}$ spiking. Biochem J 316:583-591

Dupré A, Haccard O, Jessus C (2011) Mos in the oocyte: how to use MAPK independently of growth factors and transcription to control meiotic divisions. J Signal Transduct 2011:350412

Eisen A, Reynolds GT (1985) Source and sinks for the calcium released during fertilisation of single sea urchin eggs. J Cell Biol 100:15221527

Endo Y, Kopf GS, Schultz RM (1986) Stage-specific changes in protein phosphorylation accompanying meiotic maturation of mouse oocytes and fertilization of mouse eggs. J Exp Zool 239:401-409

Feske S, Gwack Y, Prakriya M, Srikanth S, Puppel SH, Tanasa B, Hogan PG, Lewis RS, Daly M, Rao A (2006) A mutation in Orail causes immune deficiency by abrogating CRAC channel function. Nature 441:179-185

Fissore RA, Robl JM (1993) Sperm, inositol trisphosphate, and thimerosal-induced intracellular $\mathrm{Ca}^{2+}$ elevations in rabbit eggs. Dev Biol 159:122-130

Fissore RA, Dobrinsky JR, Balise JJ, Duby RT, Robl JM (1992) Patterns of intracellular $\mathrm{Ca}^{2+}$ concentrations in fertilized bovine eggs. Biol Reprod 47:960-969

Fissore RA, Pinto-Correia C, Robl JM (1995) Inositol trisphosphateinduced calcium release in the generation of calcium oscillations in bovine eggs. Biol Reprod 53:766-774

Fujimoto S, Yoshida N, Fukui T, Amanai M, Isobe T, Itagaki C, Izumi T, Perry AC (2004) Mammalian phospholipase Czeta induces oocyte activation from the sperm perinuclear matrix. Dev Biol 274:370 383

Fukami K (2002) Structure, regulation, and function of phospholipase C isozymes. J Biochem 131:293-299

Galione A, Swann K, Georgiou P, Whitaker M (1994) Regenerative and non-regenerative calcium transients in hamster eggs triggered by inositol 1,4,5-trisphosphate. J Physiol 480:465-474

Gilkey JC, Jaffe LF, Ridgway EB, Reynolds GT (1978) A free calcium wave traverses the activating egg of the medaka, Oryzias latipes. J Cell Biol 76:448-466

Gómez-Fernández C, Pozo-Guisado E, Gañán-Parra M, Perianes MJ, Alvarez IS, Martín- Romero FJ (2009) Relocalization of STIM1 in mouse oocytes at fertilization: early involvement of store-operated calcium entry. Reproduction 138:211-221
Gómez-Fernández C, López-Guerrero AM, Pozo-Guisado E, Álvarez IS, Martín-Romero FJ (2012) Calcium signaling in mouse oocyte maturation: the roles of STIM1, ORAI1 and SOCE. Mol Human Reprod 18:194-203

Hajnóczky G, Thomas AP (1994) The inositol trisphosphate calcium channel is inactivated by inositol trisphosphate. Nature 370:474 477

Halet G, Tunwell R, Balla T, Swann K, Carroll J (2002) The dynamics of plasma membrane PtdIns $(4,5) \mathrm{P}_{2}$ at fertilization of mouse eggs. $\mathrm{J}$ Cell Sci 115:2139-2149

Halet G, Tunwell R, Parkinson SJ, Carroll J (2004) Conventional PKCs regulate the temporal pattern of $\mathrm{Ca}^{2+}$ oscillations at fertilization in mouse eggs. J Cell Biol 164:1033-1044

Hardie RC (2007) TRP channels and lipids: from Drosophila to mammalian physiology. J Physiol 578:9-24

Heilbrunn LV (1937) An outline of general physiology, 1st edn. Saunders, Philadelphia

Heilbrunn LV, Wilbur KM (1937) Stimulation and nuclear breakdown in the Nereis egg. Biol Bull 73:557-564

Heytens E, Parrington J, Coward K, Young C, Lambrecht S, Yoon SY, Fissore RA, Hamer R, Deane CM, Ruas M, Grasa P, Soleimani R, Cuvelier CA, Gerris J, Dhont M, Deforce D, Leybaert L, De Sutter P (2009) Reduced amounts and abnormal forms of phospholipase C zeta (PLCzeta) in spermatozoa from infertile men. Hum Reprod 24: 2417-2428

Igusa Y, Miyazaki S (1983) Effects of altered extracellular and intracellular calcium concentration on hyperpolarizing responses of the hamster egg. J Physiol 340:611-632

Igusa Y, Miyazaki S, Yamashita N (1983) Periodic hyperpolarizing responses in hamster and mouse eggs fertilized with mouse sperm. J Physiol 340:633-647

Ito M, Nagaoka K, Kuroda K, Kawano N, Yoshida K, Harada Y, Shikano T, Miyado M, Oda S, Toshimori K, Mizukami Y, Murata T, Umezawa A, Miyazaki S, Miyado K (2010) Arrest of spermatogenesis at round spermatids in PLCZ1-deficient mice. In: Abstract at the 11th International Symposium on Spermatology. Okinawa, Japan

Ito M, Shikano T, Kuroda K, Miyazaki S (2008) Relationship between nuclear sequestration of $\mathrm{PLC} \zeta$ and termination of $\mathrm{PLC} \zeta$-induced $\mathrm{Ca}^{2+}$ oscillations in mouse eggs. Cell Calcium 44:400-410

Jaffe LA (1990) First messengers at fertilization. J Reprod Fertil Suppl 42:107-116

Jaffe LF (1983) Sources of calcium in egg activation: a review and hypothesis. Dev Biol 99:265-276

Jaffe LF (1991) The path of calcium in cytosolic calcium oscillations: a unifying hypothesis. Proc Natl Acad Sci U S A 88:9883-9887

Jellerette T, He CL, Wu H, Parys JB, Fissore RA (2000) Down-regulation of the inositol 1,4,5-trisphosphate receptor in mouse eggs following fertilization or parthenogenetic activation. Dev Biol 223:238-250

Jones KT (1998) $\mathrm{Ca}^{2+}$ oscillations in the activation of the egg and development of the embryo in mammals. Int J Dev Biol 42:1-10

Jones KT, Nixon VL (2000) Sperm-induced $\mathrm{Ca}^{2+}$ oscillations in mouse oocytes and eggs can be mimicked by photolysis of caged inositol 1 , 4,5-trisphosphate: evidence to support a continuous low level production of inositol 1, 4,5-trisphosphate during mammalian fertilization. Dev Biol 225:1-12

Jones KT, Soeller C, Cannell MB (1998) The passage of $\mathrm{Ca}^{2+}$ and fluorescent markers between the sperm and egg after fusion in the mouse. Development 125:4627-4635

Kashir J, Deguchi R, Jones C, Coward K, Stricker SA (2013a) Comparative biology of sperm actors and fertilization-induced calcium signals across the animal kingdom. Mol Reprod Dev 80:787815

Kashir J, Jones C, Mounce G, Ramadan WM, Lemmon B, Heindryckx B, de Sutter P, Parrington J, Turner K, Child T, McVeigh E, Coward K (2013b) Variance in total levels of phospholipase C zeta (PLC- $\zeta$ ) in human sperm may limit the applicability of quantitative 
immunofluorescent analysis as a diagnostic indicator of oocyte activation capability. Fertil Steril 99:107-117

Kashir J, Konstantinidis M, Jones C, Lemmon B, Lee HC, Hamer R, Heindryckx B, Deane CM, De Sutter P, Fissore RA, Parrington J, Wells D, Coward K (2012) A maternally inherited autosomal point mutation in human phospholipase C zeta (PLCC) leads to male infertility. Hum Reprod 27:222-231

Kashir J, Nomikos M, Lai FA, Swann K (2014) Sperm-induced $\mathrm{Ca}^{2+}$ release during egg activation in mammals. Biochem Biophys Res Commun 450:1204-1211

Kashir J, Nomikos M, Swann K, Lai FA (2015) PLCל or PAWP: revisiting the putative mammalian sperm factor that triggers egg activation and embryogenesis. Mol Hum Reprod 21:383-388

Kimura Y, Yanagimachi R (1995) Mouse oocytes injected with testicular spermatozoa or round spermatids can develop into normal offspring. Development 121:2397-2405

Kimura Y, Yanagimachi R, Kuretake S, Bortkiewicz H, Perry AC, Yanagimachi H (1998) Analysis of mouse oocyte activation suggests the involvement of sperm perinuclear material. Biol Reprod 58:1407-1415

Kline D, Kline JT (1992) Thapsigargin activates a calcium influx pathway in the unfertilized mouse egg and suppresses repetitive calcium transients in the fertilized egg. J Biol Chem 267:17624-17630

Kline D, Simoncini L, Mandel G, Maue RA, Kado RT, Jaffe LA (1988) Fertilization events induced by neurotransmitters after injection of mRNA in Xenopus eggs. Science 241:464-467

Knott JG, Kurokawa M, Fissore RA, Schultz RM, Williams CJ (2005) Transgenic RNA interference reveals role for mouse sperm phospholipase $\mathrm{C} \zeta$ in triggering $\mathrm{Ca}^{2+}$ oscillations during fertilization. Biol Reprod 72:992-996

Koh S, Lee K, Wang C, Cabot RA, Machaty Z (2009) STIM1 regulates store-operated $\mathrm{Ca}^{2+}$ entry in oocytes. Dev Biol 330:368-376

Koh S, Lee K, Wang C, Machaty Z (2007) Characterization of STIM1 gene expression in porcine oocytes. Biol Reprod (Suppl 1) 139

Kono T, Jones KT, Bos-Mikich A, Whittingham DG, Carroll J (1996) A cell cycle-associated change in $\mathrm{Ca}^{2+}$ releasing activity leads to the generation of $\mathrm{Ca}^{2+}$ transients in mouse embryos during the first mitotic division. J Cell Biol 132:915-923

Kouchi Z, Fukami K, Shikano T, Oda S, Nakamura Y, Takenawa T, Miyazaki S (2004) Recombinant phospholipase $\mathrm{C} \zeta$ has high $\mathrm{Ca}^{2+}$ sensitivity and induces $\mathrm{Ca}^{2+}$ oscillations in mouse eggs. J Biol Chem 279:10408-10412

Kurokawa M, Sato K, Wu H, He C, Malcuit C, Black SJ, Fukami K, Fissore RA (2005) Functional, biochemical, and chromatographic characterization of the complete $\left[\mathrm{Ca}^{2+}\right]_{\mathrm{i}}$ oscillation-inducing activity of porcine sperm. Dev Biol 285:376-392

Larman MG, Saunders CM, Carroll J, Lai FA, Swann K (2004) Cell cycle-dependent $\mathrm{Ca}^{2+}$ oscillations in mouse embryos are regulated by nuclear targeting of PLC C. J Cell Sci 117:2513-2521

Lawrence Y, Whitaker M, Swann K (1997) Sperm-egg fusion is the prelude to the initial $\mathrm{Ca}^{2+}$ increase at fertilization in the mouse. Development 124:233-241

Ledger WL (2008) Demographics of infertility. Reprod Biomed Online 18(suppl 2):11-14

Lee B, Yoon SY, Malcuit C, Parys JB, Fissore RA (2010) Inositol 1,4,5trisphosphate receptor 1 degradation in mouse eggs and impact on $\left[\mathrm{Ca}^{2+}\right]_{\mathrm{i}}$ oscillations. J Cell Physiol 222:238-247

Lee K, Wang C, Machaty Z (2012) STIM1 is required for $\mathrm{Ca}^{2+}$ signaling during mammalian fertilization. Dev Biol 367:154-162

Lee SJ, Madden PJ, Shen SS (1998) U73122 blocked the cGMP-induced calcium release in sea urchin eggs. Exp Cell Res 242:328-340

Liou J, Kim ML, Heo WD, Jones JT, Myers JW, Ferrell JE Jr, Meyer T (2005) STIM is a $\mathrm{Ca}^{2+}$ sensor essential for $\mathrm{Ca}^{2+}$-store-depletiontriggered $\mathrm{Ca}^{2+}$ influx. Curr Biol 15:1235-1241
Jaffe LA, Gould M (1985) Polyspermy-preventing mechanisms. In: Metz $\mathrm{CB}$, Monry A (eds) Biology of fertilization. Academic, Orlando, pp $223-250$

Loeb J (1899) On the nature of the process of fertilization and the artificial production of normal larvae (Plutei) from the unfertilized eggs of sea urchin. Am J Physiol 3:135-138

Machaty Z, Bonk AJ, Kühholzer B, Prather RS (2000) Porcine oocyte activation induced by a cytosolic sperm factor. Mol Reprod Dev 57: 290-295

Machaty Z, Mayes MA, Kovács LG, Balatti PA, Kim JH, Prather RS (1997) Activation of porcine oocytes via an exogenously introduced rat muscarinic M1 receptor. Biol Reprod 57:85-91

Machaty Z, Ramsoondar JJ, Bonk AJ, Bondioli KR, Prather RS (2002) Capacitative calcium entry mechanism in porcine oocytes. Biol Reprod 66:667-674

Macias MJ, Wiesner S, Sudol M (2002) WW and SH3 domains, two different scaffolds to recognize proline-rich ligands. FEBS Lett 513:30-37

Madgwick S, Levasseur M, Jones KT (2005) Calmodulin-dependent protein kinase II, and not protein kinase $\mathrm{C}$, is sufficient for triggering cell-cycle resumption in mammalian eggs. J Cell Sci 118:38493859

Marangos P, FitzHarris G, Carroll J (2003) $\mathrm{Ca}^{2+}$ oscillations at fertilization in mammals are regulated by the formation of pronuclei. Development 130:1461-1472

Martín-Romero FJ, Ortíz-de-Galisteo JR, Lara-Laranjeira J, DomínguezArroyo JA, González-Carrera E, Alvarez IS (2008) Store-operated calcium entry in human oocytes and sensitivity to oxidative stress. Biol Reprod 78:307-315

Mazia D (1937) The release of calcium in Arbacia eggs on fertilization. J Cell Comp Physiol 10:291-304

McGuinness OM, Moreton RB, Johnson MH, Berridge MJ (1996) A direct measurement of increased divalent cation influx in fertilised mouse oocytes. Development 122:2199-2206

Mehlmann LM, Carpenter G, Rhee SG, Jaffe LA (1998) SH2 domainmediated activation of phospholipase $\mathrm{C} \gamma$ is not required to initiate $\mathrm{Ca}^{2+}$ release at fertilization of mouse eggs. Dev Biol 203:221-232

Mehlmann LM, Chattopadhyay A, Carpenter G, Jaffe LA (2001) Evidence that phospholipase $\mathrm{C}$ from the sperm is not responsible for initiating $\mathrm{Ca}^{2+}$ release at fertilization in mouse eggs. Dev Biol 236:492-501

Miao YL, Stein P, Jefferson WN, Padilla-Banks E, Williams CJ (2012) Calcium influx-mediated signaling is required for complete mouse egg activation. Proc Natl Acad Sci U S A 109:4169-4174

Mignery GA, Südhof TC (1990) The ligand binding site and transduction mechanism in the inositol-1,4,5-triphosphate receptor. EMBO J 9: 3893-3898

Mikoshiba K (1993) Inositol 1,4,5-trisphosphate receptor. Trends Pharmacol Sci 14:86-89

Miyazaki S (1988) Inositol 1,4,5-trisphosphate-induced calcium release and guanine nucleotide-binding protein-mediated periodic calcium rises in golden hamster eggs. J Cell Biol 106:345-353

Miyazaki S (1991) Repetitive calcium transients in hamster oocytes. Cell Calcium 12:205-216

Miyazaki S, Igusa Y (1981) Ca-dependent action potential and Cainduced fertilization potential in golden hamster eggs. In: Ohnishi ST, Endo M (eds) The mechanism of gated calcium transport across biological membranes. Academic, New York, pp pp 305-pp 311

Miyazaki S, Katayama Y, Swann K (1990) Synergistic activation by serotonin and GTP analogue and inhibition by phorbol ester of cyclic $\mathrm{Ca}^{2+}$ rises in hamster eggs. J Physiol 426:209-227

Miyazaki S, Shirakawa H, Nakada K, Honda Y (1993) Essential role of the inositol 1,4,5- trisphosphate receptor/ $\mathrm{Ca}^{2+}$ release channel in $\mathrm{Ca}^{2+}$ waves and $\mathrm{Ca}^{2+}$ oscillations at fertilization of mammalian eggs. Dev Biol 158:62-78 
Miyazaki S, Yuzaki M, Nakada K, Shirakawa H, Nakanishi S, Nakade S, Mikoshiba K (1992) Block of $\mathrm{Ca}^{2+}$ wave and $\mathrm{Ca}^{2+}$ oscillation by antibody to the inositol 1,4,5-trisphosphate receptor in fertilized hamster eggs. Science 257:251-255

Mohri T, Shirakawa H, Oda S, Sato MS, Mikoshiba K, Miyazaki S (2001) Analysis of $\mathrm{Mn}^{2+} / \mathrm{Ca}^{2+}$ influx and release during $\mathrm{Ca}^{2+}$ oscillations in mouse eggs injected with sperm extract. Cell Calcium 29:311-325

Murnane JM, De Felice LJ (1993) Electrical maturation of the murine oocyte: an increase in calcium current coincides with acquisition of meiotic competence. Zygote 1:49-60

Nalefski EA, Falke JJ (1996) The C2 domain calcium-binding motif: Structural and functional diversity. Protein Sci 5:2375-2390

Nixon VL, Levasseur M, McDougall A, Jones KT (2002) $\mathrm{Ca}^{2+}$ oscillations promote $\mathrm{APC} / \mathrm{C}$ - dependent Cyclin $\mathrm{B} 1$ degradation during metaphase arrest and completion of meiosis in fertilizing mouse eggs. Curr Biol 12:746-750

Nomikos M, Blayney LM, Larman MG, Campbell K, Rossbach A, Saunders CM, Swann K, Lai FA (2005) Role of phospholipase C$\zeta$ domains in $\mathrm{Ca}^{2+}$-dependent phosphatidylinositol 4,5-bisphosphate hydrolysis and cytoplasmic $\mathrm{Ca}^{2+}$ oscillations. J Biol Chem 280: 31011-31018

Nomikos M, Elgmati K, Theodoridou M, Georgilis A, Gonzalez-Garcia JR, Nounesis G, Swann K, Lai FA (2011). Novel regulation of PLCל activity via its XY-linker. Biochem J 438:427-432

Nomikos M, Kashir J, Swann K, Lai FA (2013) Sperm PLC C: from structure to $\mathrm{Ca}^{2+}$ oscillations, egg activation and therapeutic potential. FEBS Lett 587:3609-3616

Nomikos M, Mulgrew-Nesbitt A, Pallavi P, Mihalyne G, Zaitseva I, Swann K, Lai FA, Murray D, McLaughlin S (2007) Binding of phosphoinositide-specific phospholipase $\mathrm{C}-\zeta$ (PLC- $\zeta$ ) to phospholipid membranes: potential role of an unstructured cluster of basic residues. J Biol Chem 282:16644-16653

Nomikos M, Sanders JR, Kashir J, Sanusi R, Buntwal L, Love D, Ashley P, Sanders D, Knaggs P, Bunkheila A, Swann K, Lai FA (2015a) Functional disparity between human PAWP and $\mathrm{PLC} \zeta$ in the generation of $\mathrm{Ca}^{2+}$ oscillations for oocyte activation. Mol Hum Reprod Jun 26. pii: gav034. [Epub ahead of print]

Nomikos M, Sanders JR, Theodoridou M, Kashir J, Matthews E, Nounesis G, Lai FA, Swann K (2014) Sperm-specific post-acrosomal WW-domain binding protein (PAWP) does not cause $\mathrm{Ca}^{2+}$ release in mouse oocytes. Mol Hum Reprod 20:938-947

Nomikos M, Swann K, Lai FA (2015b) Is PAWP the "real" sperm factor? Asian J Androl 17:444-446

Ombelet W, Cooke I, Dyer S, Serour G, Devroey P (2008) Infertility and the provision of infertility medical services in developing countries. Hum Reprod Update 14:605-621

Ozil JP, Huneau D (2001) Activation of rabbit oocytes: the impact of the $\mathrm{Ca}^{2+}$ signal regime on development. Development 128:917-928

Ozil JP, Markoulaki S, Toth S, Matson S, Banrezes B, Knott JG, Schultz RM, Huneau D, Ducibella T (2005) Egg activation events are regulated by the duration of a sustained $\left[\mathrm{Ca}^{2+}\right]_{\text {cyt }}$ signal in the mouse. Dev Biol 282:39-54

Ozil JP, Banrezes B, Tóth S, Pan H, Schultz RM (2006) $\mathrm{Ca}^{2+}$ oscillatory pattern in fertilized mouse eggs affects gene expression and development to term. Dev Biol 300:534-544

Palermo GD, Neri QV, Takeuchi T, Rosenwaks Z (2009) ICSI: where we have been and where we are going. Semin Reprod Med 27:191-201

Parrington J, Jones M, Tunwell R, Devader C, Katan M, Swann K (2002) Phospholipase $\mathrm{C}$ isoforms in mammalian spermatozoa: potential components of the sperm factor that causes $\mathrm{Ca}^{2+}$ release in eggs. Reproduction 123:31-39

Parrington J, Swann K, Shevchenko VI, Sesay AK, Lai FA (1996) Calcium oscillations in mammalian eggs triggered by a soluble sperm protein. Nature 379:364-368

Pepperell JR, Kommineni K, Buradagunta S, Smith PJ, Keefe DL (1999) Transmembrane regulation of intracellular calcium by a plasma membrane sodium/calcium exchanger in mouse ova. Biol Reprod 60:1137-1143

Perry AC, Wakayama T, Cooke IM, Yanagimachi R (2000) Mammalian oocyte activation by the synergistic action of discrete sperm head components: induction of calcium transients and involvement of proteolysis. Dev Biol 217:386-393

Petersen C, Berridge MJ, Borgese MF, Bennett DL (1995) Putative capacitative calcium entry channels: expression of Drosophila trp and evidence for the existence of vertebrate homologues. Biochem J 311:41-44

Prather RS (1996) Progress in cloning embryos from domesticated livestock. Proc Soc Exp Biol Med 212:38-43

Putney JW Jr (1986) A model for receptor-regulated calcium entry. Cell Calcium 7:1-12

Putney JW, Tomita T (2012) Phospholipase C signaling and calcium influx. Adv Biol Regul 52:152-164

Ridgway EB, Gilkey JC, Jaffe LF (1977) Free calcium increases explosively in activating medaka eggs. Proc Natl Acad Sci U S A 74:623627

Reynolds CH, Garwood CJ, Wray S, Price C, Kellie S, Perera T, Zvelebil M, Yang A, Sheppard PW, Varndell IM, Hanger DP, Anderton BH (2008) Phosphorylation regulates tau interactions with Src homology 3 domains of phosphatidylinositol 3-kinase, phospholipase $\mathrm{C} \gamma 1$, Grb2, and Src family kinases. J Biol Chem 283:18177-18186

Rice A, Parrington J, Jones KT, Swann K (2000) Mammalian sperm contain a $\mathrm{Ca}^{2+}$-sensitive phospholipase $\mathrm{C}$ activity that can generate $\mathrm{InsP}_{3}$ from $\mathrm{PIP}_{2}$ associated with intracellular organelles. Dev Biol 228:125-135

Ringer S (1883) A further contribution regarding the influence of the different constituents of the blood on the contraction of the heart. J Physiol 4:29-43

Rogers NT, Hobson E, Pickering S, Lai FA, Braude P, Swann K (2004) Phospholipase $\mathrm{C} \zeta$ causes $\mathrm{Ca}^{2+}$ oscillations and parthenogenetic activation of human oocytes. Reproduction 128:697-702

Roos J, DiGregorio PJ, Yeromin AV, Ohlsen K, Lioudyno M, Zhang S, Safrina O, Kozak JA, Wagner SL, Cahalan MD, Veliçelebi G, Stauderman KA (2005) STIM1, an essential and conserved component of store-operated Ca2+ channel function. J Cell Biol 169:435445

Runft LL, Watras J, Jaffe LA (1999) Calcium release at fertilization of Xenopus eggs requires type $\mathrm{I} \mathrm{IP}_{3}$ receptors, but not $\mathrm{SH} 2$ domainmediated activation of PLC $\gamma$ or $\mathrm{G}_{\mathrm{q}}$-mediated activation of PLC $\beta$. Dev Biol 214:399-411

Saunders CM, Larman MG, Parrington J, Cox LJ, Royse J, Blayney LM, Swann K, Lai FA (2002) PLC $\zeta$ : a sperm-specific trigger of $\mathrm{Ca}^{2+}$ oscillations in eggs and embryo development. Development 129: 3533-3544

Saunders CM, Swann K, Lai FA (2007) PLC $\zeta$, a sperm-specific PLC and its potential role in fertilization. Biochem Soc Symp 74:23-36

Schultz RM, Kopf GS (1995) Molecular basis of mammalian egg activation. Curr Top Dev Biol 30:21-62

Sette C, Bevilacqua A, Bianchini A, Mangia F, Geremia R, Rossi P (1997) Parthenogenetic activation of mouse eggs by microinjection of a truncated c-kit tyrosine kinase present in spermatozoa. Development 124:2267-2274

Sette C, Paronetto MP, Barchi M, Bevilacqua A, Geremia R, Rossi P (2002) Tr-kit-induced resumption of the cell cycle in mouse eggs requires activation of a Src-like kinase. EMBO J 21:5386-5395

Shapira H, Lupu-Meiri M, Lipinsky D, Oron Y (1996) Agonist-evoked calcium efflux from a functionally discrete compartment in Xenopus oocytes. Cell Calcium 19:201-210

Shiina Y, Kaneda M, Matsuyama K, Tanaka K, HiroiM DK (1993) Role of the extracellular $\mathrm{Ca}^{2+}$ on the intracellular $\mathrm{Ca}^{2+}$ changes in fertilized and activated mouse oocytes. J Reprod Fertil 97:143-150

Shreeve J (1983) Calcium and The Man. MBL Newslett 8 
Snow P, Yim DL, Leibow JD, Saini S, Nuccitelli R (1996) Fertilization stimulates an increase in inositol trisphosphate and inositol lipid levels in Xenopus eggs. Dev Biol 180:108-118

Steinhardt RA, Epel D (1974) Activation of sea-urchin eggs by a calcium ionophore. Proc Natl Acad Sci U S A 71:1915-1919

Stricker SA (1999) Comparative biology of calcium signaling during fertilization and egg activation in animals. Dev Biol 211:157-176

Sudol M, Hunter T (2000) NeW wrinkles for an old domain. Cell 103: 1001-1004

Swann K (1990) A cytosolic sperm factor stimulates repetitive calcium increases and mimics fertilization in hamster eggs. Development 110:1295-1302

Swann K (1992) Different triggers for calcium oscillations in mouse eggs involve a ryanodine-sensitive calcium store. Biochem J 287:79-84

Swann K (1994) $\mathrm{Ca}^{2+}$ oscillations and sensitization of $\mathrm{Ca}^{2+}$ release in unfertilized mouse eggs injected with a sperm factor. Cell Calcium 15:331-339

Swann K, Lai FA (2013) PLC $\zeta$ and the initiation of $\mathrm{Ca}^{2+}$ oscillations in fertilizing mammalian eggs. Cell Calcium 53:55-62

Swann K, Ozil JP (1994) Dynamics of the calcium signal that triggers mammalian egg activation. Int Rev Cytol 152:183-222

Swann K, Whitaker M (1986) The part played by inositol trisphosphate and calcium in the propagation of the fertilization wave in sea urchin eggs. J Cell Biol 103:2333-2342

Swann K, Saunders CM, Rogers NT, Lai FA (2006) PLCC(zeta): A sperm protein that triggers $\mathrm{Ca}^{2+}$ oscillations and egg activation in mammals. Semin Cell Dev Biol 17:264-273

Takahashi T, Kikuchi T, Kidokoro Y, Shirakawa H (2013) $\mathrm{Ca}^{2+}$ influxdependent refilling of intracellular $\mathrm{Ca}^{2+}$ stores determines the frequency of $\mathrm{Ca}^{2+}$ oscillations in fertilized mouse eggs. Biochem Biophys Res Commun 430:60-65

Turner PR, Jaffe LA, Fein A (1986) Regulation of cortical vesicle exocytosis in sea urchin eggs by inositol 1,4,5-trisphosphate and a GTPbinding protein. J Cell Biol 102:70-76

Turner PR, Sheetz MP, Jaffe LA (1984) Fertilization increases the polyphosphoinositide content of sea urchin eggs. Nature 310:414415

Vig M, Peinelt C, Beck A, Koomoa DL, Rabah D, Koblan-Huberson M, Kraft S, Turner H, Fleig A, Penner R, Kinet JP (2006) CRACM1 is a plasma membrane protein essential for store-operated $\mathrm{Ca}^{2+}$ entry. Science 312:1220-1223

Wang C, Lee K, Gajdócsi E, Bali Papp A, Machaty Z (2012) Orai1 mediates store-operated $\mathrm{Ca}^{2+}$ entry during fertilization in mammalian oocytes. Dev Biol 365:414-423

Wang C, Zhang L, Jaeger LA, Machaty Z (2015) Store-operated $\mathrm{Ca}^{2+}$ entry sustains the fertilization $\mathrm{Ca}^{2+}$ signal in pig eggs. Biol Reprod 93:25. doi:10.1095/biolreprod.114.126151

Wassarman PM, Jovine L, Qi H, Williams Z, Darie C, Litscher ES (2005) Recent aspects of mammalian fertilization research. Mol Cell Endocrinol 234:95-103

Weiss A (1993) T cell antigen receptor signal transduction: a tale of tails and cytoplasmic protein-tyrosine kinases. Cell 73:209-212

Whitaker M (1996) Control of meiotic arrest. Rev Reprod 1:127-135

Whitaker MJ, Steinhardt RA (1982) Ionic regulation of egg activation. Q Rev Biophys 15:593-666

Williams CJ, Schultz RM, Kopf GS (1992) Role of G proteins in mouse egg activation: stimulatory effects of acetylcholine on the ZP2 to $\mathrm{ZP} 2 \mathrm{f}$ conversion and pronuclear formation in eggs expressing a functional $\mathrm{m} 1$ muscarinic receptor. Dev Biol 151:288-296

Wolosker H, Kline D, Bian Y, Blackshaw S, Cameron AM, Fralich TJ, Schnaar RL, Snyder SH (1998) Molecularly cloned mammalian glucosamine-6-phosphate deaminase localizes to transporting epithelium and lacks oscillin activity. FASEB J 12:91-99

Wu AT, Sutovsky P, Manandhar G, Xu W, Katayama M, Day BN, Park KW, Yi YJ, Xi YW, Prather RS, Oko R (2007a) PAWP, a spermspecific WW domain-binding protein, promotes meiotic resumption and pronuclear development during fertilization. J Biol Chem 282: 12164-12175

Wu AT, Sutovsky P, Xu W, van der Spoel AC, Platt FM, Oko R (2007b) The postacrosomal assembly of sperm head protein, PAWP, is independent of acrosome formation and dependent on microtubular manchette transport. Dev Biol 312:471-483

Wu H, He CL, Fissore RA (1997) Injection of a porcine sperm factor triggers calcium oscillations in mouse oocytes and bovine eggs. Mol Reprod Dev 46:176-189

Yanagimachi R (1994) Mammalian fertilization. In: Knobil E, Neill JD (eds) The physiology of reproduction, 2nd edn. Raven, New York, pp 189-317

Yim DL, Opresko LK, Wiley HS, Nuccitelli R (1994) Highly polarized EGF receptor tyrosine kinase activity initiates egg activation in Xenopus. Dev Biol 162:41-55

Yoda A, Oda S, Shikano T, Kouchi Z, Awaji T, Shirakawa H, Kinoshita $\mathrm{K}$, Miyazaki S (2004) $\mathrm{Ca}^{2+}$ oscillation-inducing phospholipase $\mathrm{C}$ zeta expressed in mouse eggs is accumulated to the pronucleus during egg activation. Dev Biol 268:245-257

Yoneda A, Kashima M, Yoshida S, Terada K, Nakagawa S, Sakamoto A, Hayakawa K, Suzuki K, Ueda J, Watanabe T (2006) Molecular cloning, testicular postnatal expression, and oocyte-activating potential of porcine phospholipase C $\zeta$. Reproduction 132:393-401

Yoon SY, Fissore RA (2007) Release of phospholipase $\mathrm{C} \zeta$ and $\left[\mathrm{Ca}^{2+}\right]_{i}$ oscillation-inducing activity during mammalian fertilization. Reproduction 134:695-704

Yoon SY, Jellerette T, Salicioni AM, Lee HC, Yoo MS, Coward K, Parrington J, Grow D, Cibelli JB, Visconti PE, Mager J, Fissore RA (2008) Human sperm devoid of PLC, zeta 1 fail to induce $\mathrm{Ca}^{2+}$ release and are unable to initiate the first step of embryo development. J Clin Invest 118:3671-3681

Young C, Grasa P, Coward K, Davis LC, Parrington J (2009) Phospholipase $\mathrm{C}$ zeta undergoes dynamic changes in its pattern of localization in sperm during capacitation and the acrosome reaction. Fertil Steril 91:2230-2242

Yu F, Sun L, Machaca K (2009) Orai1 internalization and STIM1 clustering inhibition modulate SOCE inactivation during meiosis. Proc Natl Acad Sci U S A 106:17401-17406

Yu Y, Halet G, Lai FA, Swann K (2008) Regulation of diacylglycerol production and protein kinase $\mathrm{C}$ stimulation during sperm- and

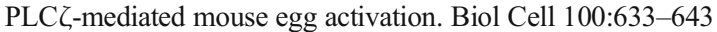

Yu Y, Nomikos M, Theodoridou M, Nounesis G, Lai FA, Swann K (2012) PLC $\zeta$ causes $\mathrm{Ca}^{2+}$ oscillations in mouse eggs by targeting intracellular and not plasma membrane $\mathrm{PI}(4,5) \mathrm{P}_{2}$. Mol Biol Cell 23: 371-380

Zhang SL, Yeromin AV, Zhang XH, Yu Y, Safrina O, Penna A, Roos J, Stauderman KA, Cahalan MD (2006) Genome-wide RNAi screen of $\mathrm{Ca}^{2+}$ influx identifies genes that regulate $\mathrm{Ca}^{2+}$ releaseactivated $\mathrm{Ca}^{2+}$ channel activity. Proc Natl Acad Sci U S A 103: 9357-9362

Zheng L, Krishnamoorthi R, Zolkiewski M, Wang X (2000) Distinct $\mathrm{Ca}^{2+}$ binding properties of novel $\mathrm{C} 2$ domains of plant phospholipase $\mathrm{D} \alpha$ and $\beta$. J Biol Chem 275:19700-19706

Zucker RS, Steinhardt RA (1978) Prevention of the cortical reaction in fertilized sea urchin eggs by injection of calcium-chelating ligands. Biochim Biophys Acta 541:459-466 